\title{
TROSKA BISKUPÓW KUJAWSKO-KALISKICH O JASNĄ GÓRE W OKRESIE PO POWSTANIU STYCZNIOWYM (1864-1914)
}

Sytuacja Kościoła katolickiego pod zaborem rosyjskim była bardzo trudna. Represyjna polityka carska wobec Kościoła katolickiego polegała m. in. na odebraniu klasztorom własności materialnej, a potem na stopniowej ich kasacie. Rosyjskie prawodawstwo, które było wielokrotnie zaostrzane, prowadziło do stopniowego wymarcia klasztorów. Dekretemkasacyjnym większośćklasztorów w Królestwie Polskim z 1864 r. zabroniono zakonnikom kontaktować się ze swoimi władzami za granicą oraz prowadzenia własnych studiów ${ }^{1}$.

${ }^{*}$ ks. Bronisław Czaplicki - dr hab. historii.

${ }^{1}$ Prawodawstwo to jest na ogół znane i przytaczane w opracowaniach podręcznikowych. Aleksander II 27 X/8 XI 1864 r. podpisał „ukaz”, który był wyrazem jego „zatroskania” o dobro kraju i Kościoła. Wzorem innych krajów poddał on klasztory pod zwierzchnictwo biskupów diecezjalnych, likwidując funkcje generałów, prowincjałów i zakonnych kapituł. Klasztory, które miały jakiekolwiek kontakty z powstańcami, miały zostać zlikwidowane. Szkoły i szpitale, istniejące dotychczas przy klasztorach, miały zostać poddane władzy odpowiednich ministerstw. Car postanowił w Królestwie Polskim pozostawić jedynie niewielką liczbę klasztorów tzw. etatowych oraz pewną ilość nieetatowych. Wszelkie majątki klasztorne zostały upaństwowione, a dochody z nich miały trafiać do skarbu państwa, które wzięło na siebie obowiązek utrzymania klasztorów i wypłacania pensji zakonnikom. Pozostawiono w Królestwie Polskim jako „etatowe” 25 klasztorów męskich i 10 żeńskich, oraz pewną ilość jako „nieetatowe”. Nieetatowe miały ulec likwidacji po zmniejszeniu się ilości zakonników poniżej ośmiu. Władze wprost zachęcały osoby zakonne do wyjazdu za granicę lub do porzucenia stanu zakonnego, obiecując im wypłatę pensji. W klasztorze etatowym mogło być najwyżej 14 zakonników. Jedynie dla Jasnej Góry wyznaczono limit 24 zakonników. Oznaczało to, że zakonnicy z klasztorów zlikwidowanych lub nieetatowych mogli przechodzić do etatowych dopiero po obniżeniu w nich liczby zakonników poniżej wyznaczonego limitu. Inni, pragnący pozostać duchownymi, mogli pozostać wikariuszami lub organistami w diecezji. Ziemie, lasy, łąki, gospodarstwa rybne, młyny czy domy klasztorne i parafialne, nie będące bezpośrednio potrzebne kościołowi, zostały przeznaczone dla biednych chłopów. Kapitały kościelnych osób prawnych, złożone w Banku Polskim, zostały znacjonalizowane już ukazem z 19 II/2 III 1864. Według 18 artykułu „ukazu” dochody z ,poduchownej” własności przechodziły na skarb państwa, lecz miały być przeznaczane na utrzymanie klasztorów, na pensje dla zakonników, 
Władze represjonowały kapłanów i zakonników za to, że pomagali powstańcom. Represje nie ominęły i biskupów. Dekret cara Aleksandra II z 8 listopada 1864 r., oddający władzę nad klasztorami biskupom, okazał się groźny tak dla władzy diecezjalnej, jak i dla istniejących jeszcze klasztorów. Aby nie pozostawić klasztorów na pastwę urzędników carskich, Stolica Apostolska 30 stycznia 1965 r. prawo to potwierdziła. Gdyby biskupi odmówili przyjęcia klasztorów pod swoją jurysdykcję, stałyby się one jeszcze łatwiejszym łupem władz. Chociaż pozycja biskupów wobec władz rosyjskich nie była wiele silniejsza, to jednak próbowali oni pomagać klasztorom lub je bronić. Czynili to osobiście oraz poprzez zatwierdzanego przez władze państwowe wizytatora klasztorów ${ }^{2}$.

Spotykamy nieraz w publikacjach opinie, jakoby biskupi i wizytatorzy klasztorów przyczyniali się do kasaty klasztorów. Takie oskarżenia wynikają z przekonania, że biskupi i wizytatorzy byli wolni w swoich decyzjach ${ }^{3}$. Już jednak sami paulini, żyjący w tych trudnych czasach, polemizowali z tą krzywdzącą opiniąa ${ }^{4}$. Przecież to władze państwowe decydowały o tym, kto będzie należał do hierarchii Kościoła i zatwierdzały kandydatów na wszelkie kościelne stanowiska począwszy od biskupów, poprzez profesorów, członków kapituł, dziekanów, przeorów klasztorów, proboszczów i wikariuszy parafialnych. Niemożliwą więc rzeczą było, aby jakiekolwiek stanowisko kościelne objęła osoba, jawnie występująca przeciw postanowieniom władzy państwowej.

Władze zlikwidowały wszystkie klasztory paulinów, oprócz Jasnej Góry i początkowo klasztoru przy kościele św. Barbary. Paulini z klasztoru przy kościele parafialnym św. Zygmunta, podobnie jak i ich współbracia z filii w Konopiskach i w innych klasztorach, zostali mocą ukazu carskiego w nocy z 27 na 28 listopada 1864 r. przetransportowani na Jasną Górę. Biskup diecezji kujawsko-kaliskiej, do której należała wówczas Częstochowa, musiał znaleźć miejsce pracy w diecezji dla „nadliczbowych” zakonników5 ${ }^{5}$ Rządcy diecezji starali się posyłać paulinów

na zabezpieczenie nabożeństw, na utrzymanie dobroczynności, na zasiłki dla zasłużonych dla państwa osób duchownych, na podtrzymywanie oświaty. Śluby uroczyste zakonnicy mogli składać dopiero po osiągnięciu wieku 30 lat. Ukaz carski z 1864 r. skasował prawie wszystkie klasztory paulinów, pozostawiając konwent na Jasnej Górze i przy kościele św. Barbary. Ten drugi został zlikwidowany w czasie późniejszym. Represyjne prawodawstwo rosyjskie w stosunku do zakonów katolickich w Królestwie Polskim, zwłaszcza odnoszące się do klasztoru jasnogórskiego, zebrane jest w polskim tłumaczeniu w Archiwum Jasnej Góry Por. Archiwum Jasnej Góry (AJG) 2366, Sprawa Pius Przeździecki - Przeor Rejman, 1864-1909, cz. III, s. 1-19 - Kronika, napisana przez o. Czesława Dąbrowskiego za rządów o. Euzebiusza Rejmana, 1864-1909. Por. też: AJG, o. Piotr Markiewicz, Kronika Zakonu Paulinów

${ }^{2}$ Por. J. Związek, Kościół częstochowski na przełomie wieków, w: Częstochowa. Dzieje miasta i klasztoru jasnogórskiego, t. 2 - Wokresie niewoli 1793-1918, red. R. Kołodziejczyk, Częstochowa 2005, s. 139.

3 J. Zbudniewek, Konwent paulinów jasnogórskich, „Studia Claromontana” (dalej: SC) 18 (1998) s. 30.

${ }^{4}$ Por. AJG 2366, cz. III - Kronika, napisana przez o. Czesława Dąbrowskiego za rządów o. Euzebiusza Rejmana, 1864-1909, s. 26-32.

5 „Etat” Jasnej Góry został ograniczony do 24 osób, dlatego paulini, by uniknąć sekularyzacji, musieli przyjąć pracę duszpasterzy w diecezjach. Por. J. Zbudniewek, Jasna Góra w okresie niewoli 
jako proboszczów lub wikariuszy do kościołów przy skasowanych klasztorach paulińskich lub nawet $\mathrm{w}$ innych parafiach ${ }^{6}$.

Represje popowstaniowe odbiły się na klasztorze jasnogórskim. Początkowo klasztor jasnogórski przepełniony był zakonnikami ze zlikwidowanych klasztorów paulińskich, dlatego władze państwowe początkowo tolerowały pobyt w nim większej liczby zakonników niż dopuszczonych 24 . Ponieważ byli to przeważnie starsi ojcowie a warunki zdrowotne były tam bardzo trudne, liczba zakonników szybko zmniejszała się, by pod koniec XIX w. spaść poniżej dopuszczalnego limitu. Nowicjatu i studiów teologicznych w klasztorze nie było wolno prowadzić.

Władze stworzyły pozory troski o klasztory i inne instytucje kościelne. Rozdzielały pochodzące z funduszu kościelnego środki środki na pensje dla zakonników w klasztorach ,etatowych”. Ponadto kontrolowały wszelkie ofiary, składane w klasztorze, nie wyłączając ofiar na Msze święte. Ofiary musiały być wpisywane do sznurowanych ksiąg rozliczeniowych ${ }^{7}$. W celu kontrolowania ofiar, składanych na Jasnej Górze, władze powołały specjalne Kolegium, składające się z kilku osób świeckich, zatwierdzanych przez gubernatora ${ }^{8}$. Podobny sposób kontroli wszelkich spraw materialnych w parafiach zapewniały „dozory kościelne”, do których należało gospodarowanie pieniędzmi parafialnymi ${ }^{9}$.

Poniżej postaram się na podstawie źródeł archiwalnych przedstawić rolę, którą w stosunku do Jasnej Góry po powstaniu styczniowym odegrali poszczególni rządcy oraz wizytatorzy klasztorów diecezji kujawsko-kaliskiej. Rządcami w tym

narodowej, w: Częstochowa. Dzieje miasta i klasztoru jasnogórskiego, t. 2 -W okresie niewoli 1793-1918, red. R. Kołodziejczyk, Częstochowa 2005, s. 53.

${ }^{6}$ Archiwum Diecezji Włocławskiej (ADWł) V 21, Akta konsystorza generalnego kaliskiego - zakony, Paulini Jasna Góra 1863-1877 (Uwaga: w rzeczywistości akta obejmują lata: 18541899). (Dalej teczkę tę cytuję: ADWł, V 21 - Paulini). Zawiera ona wiele cennego materiału o Jasnej Górze w relacji do władz diecezjalnych. Są to dokumenty zgromadzone przez kolejnych wizytatorów klasztorów w diecezji kujawsko-kaliskiej. Mankamentem, utrudniającym cytowanie tych dokumentów jest brak paginacji w teczce i sposób zszycia, który sprawia, że niektóre dokumenty są podzielone na części. Na ogół jednak dokumenty zostały ułożone chronologicznie. Przy powoływaniu się na nie będziemy zmuszeni podawać nadawcę i adresata dokumentu oraz datę jego wystawienia.

${ }^{7}$ E. Rejman, Memoriat do sekretarza Kongregacji ds. zakonnych kard. Teodora Valfré di Bonzo, SC, 13 (1993) s. 237-238.

${ }^{8}$ Komitet ten stanowiły trzy osoby, zatwierdzone na tym stanowisku przez gubernatora. Przedstawiciel władzy zawiadamiał członków tego komitetu i przeora i w jego obecności otwierano opieczętowane skarbonki, liczono pieniądze i kontrolowano księgi finansowe. Informacja ta znajduje potwierdzenie w wielu dokumentach, zgromadzonych w zespole: Akta miasta Częstochowy. Por. Archiwum Państwowe w Częstochowie (dalej: APCz), Akta miasta Częstochowy, teczki dotyczące spraw kościelnych.

9 „Dozór” stanowiła grupa, w skład której wchodził prezydent miasta lub wójt gminy, dziekan i trzej członkowie, wybierani na wiecu parafian. 3-osobowy skład członków dozoru zatwierdzał gubernator piotrkowski. Dozory, jak podaje Sikorski, zostały powołane do życia przez rosyjskie władze państwowe po Kongresie Wiedeńskim aktami z lat 1817 i 1823. Por. R. Sikorski, Materiaty archiwalne dotyczące Kościoła rzymskokatolickiego w okresie II Rzeczypospolitej w zespole: Akta miasta Częstochowy (1759-1945), „Szkice Archiwalno-Historyczne”, 3 (2007) s. 115. 
czasie byli kolejno: biskup Jan Michał Marszewski ${ }^{10}$, wikariusze kapitulni: ks. Klemens Skupieński ${ }^{11}$ i ks. Florian Kosiński (krótko), biskup Wincenty ChościakPopiel $^{12}$, bp Aleksander Bereśniewicz ${ }^{13}$ i bp Stanisław Zdzitowiecki ${ }^{14}$.

Źródłem do zapoznania się z troską o Jasną Górę poszczególnych rządców diecezji kujawsko-kaliskiej są zasoby archiwalne zgromadzone w Rosyjskim Państwowym Archiwum Historycznym w Petersburgu (RGIA), w Archiwum Jasnej Góry (AJG), w Archiwum Diecezji Włocławskiej (ADWł) i Archiwum Państwowym w Częstochowie. W pierwszych dwu archiwach interesujący nas materiał rozproszony jest $\mathrm{w}$ różnych jednostkach ${ }^{15}$. We Włocławku zachowała się natomiast obszerna teczka akt wypracowanych przez kolejnych wizytatorów klasztorów diecezji, poczynając od ks. Józefa Rzewuskiego do ks. Franciszka Stopie-

${ }^{10}$ Ks. Józef Rzewuski (1811-1878). Wyświęcony w r. 1834, zajmował szereg odpowiedzialnych funkcji w diecezji. Jako proboszcz częstochowski został zainstalowany przez bpa Marszewskiego 25 VII $1866 \mathrm{r}$.

${ }^{11}$ Ks. prałat Klemens Skupieński został wikariuszem kapitulnym diecezji kujawsko-kaliskiej 9 IX 1867 r. Rezydował w Piotrkowie. Zmarł 3 X 1873 r.

${ }^{12}$ Wincenty Teofil Chościak-Popiel (1825-1912). Wyświęcony na kapłana w 1849. Studiował w Lowanium i Rzymie. W 1863 r. został biskupem płockim. W 1868 r. zesłany do Nowgorodu w Rosji. Po powrocie w 1876 r. został biskupem kujawsko-kaliskim, a w 1883 arcybiskupem warszawskim.

${ }^{13}$ Bereśniewicz Aleksander Kazimierz (1823-1902). Ur. na Litwie, studiował w seminarium duchownym w Worniach (ówczesna stolica diecezji żmudzkiej). Skierowany do Akademii Duchownej w Wilnie, wraz z nią przeniósł się do Petersburga, pełniąc przez pewien czas funkcję jej rektora. W 1857 r. został sufraganem żmudzkim, a potem wikariuszem kapitulnym (1875-1883). Po przeniesieniu do Włocławka prawie do końca życia pozostawał na stanowisku biskupa diecezji kujawsko-kaliskiej. Por. W. Kujawski, Aleksander Kazimierz Bereśniewicz (1823-1902). Biskup kujawsko-kaliski (1883-1902), Wyd. Nauk. UMK, Toruń 1910; Tenże, Biskup kujawsko-kaliski Aleksander Kazimierz Bereśniewicz (1883-1902), w: Veritati serviens. Księga Pamiątkowa Ojcu Profesorowi Januszowi Zbudniewkowi zp, wyd. UKSW, Warszawa 2009, s. 179-201.

${ }^{14}$ Stanisław Zdzitowiecki (1854-1927). Ur. w Barczkowicach w Ziemi Piotrkowskiej, w rodzinie ziemiańskiej. Ukończył seminarium duchowne w Warszawie. Po święceniach w 1877 r. pracował jako wikariusz w parafiach warszawskich: na Woli, Solcu i Lesznie. Potem studiował prawo kanoniczne w Rzymie na Uniwersytecie Gregoriańskim. Od 1883 r. pracował w diecezji sandomierskiej jako kanclerz kurii i profesor seminarium duchownego, a po śmierci bpa Sotkiewicza został administratorem diecezji. 23 XI 1902 przyjął sakrę biskupią w Petersburgu z rąk bpa Jerzego Szembeka jako nowy biskup kujawsko-kaliski. Ingres do katedry włocławskiej odbył 2 XII 1902. Często odwiedzał Jasną Górę. Por. J. Zbudniewek., Konwent paulinów jasnogórskich, SC, 18 (1998) s. 30 .

${ }^{15}$ Por. B. Czaplicki, Dokumenty rosyjskie z początku XX w. na temat Jasnej Góry, „Archiwa, Biblioteki i Muzea Kościelne" (dalej: ABMK), 95 (2011) s. 11-32. 
rzyńskiego ${ }^{16}$. Archiwum Państwowe w Częstochowie zawiera dokumenty magistratu miasta Częstochowa ${ }^{17}$.

Postawiony sobie cel pragnę osiągnąc w następujący sposób. Początkowo przedstawię zaangażowanie w sprawy Jasnej Góry poszczególnych wizytatorów klasztorów. Potem wyakcentuję rolę biskupów i innych rządców diecezji w dwu aspektach: troski o powołania i troski o rozwiązanie wewnętrznych problemów klasztoru jasnogórskiego, które wynikały nie tylko z destrukcyjnych działań władz państwowych, lecz również z kłopotów wewnętrznych.

\section{Wizytator klasztorów pomocnikiem biskupa}

Władze państwowe żądały od rządcy diecezji sprawozdań o stanie klasztorów. Materiału do takich sprawozdań dostarczał wizytator. Obowiązki wizytatora klasztorów, określone były nie tyle przez biskupa, co przez władze państwowe. Sprawozdania, jakie pisał wizytator, musiały oczywiście uwzględniać sprawy finansowe klasztoru. Władze żądały np. dokładnej informacji o tym, czy zmarły zakonnik pozostawił jakąś własność ${ }^{18}$.

Rolę wizytatorów klasztorów spełniało w tym czasie kolejno kilku kapłanów: prał. Józef Rzewuski, kan. Józef Kozłowski, prał. Franciszek Stopierzyński i prał. Michał Lorentowicz. Dwaj z nich (ks. Rzewuski i ks. Lorentowicz) sprawowali swoją funkcję, mieszkając w Częstochowie. Wizytatorzy pozostawali na stanowisku, chociaż zmieniali się rządcy diecezji. Świadczy to niewątpliwie o dobrym wypełnianiu przez nich swojej funkcji kościelnej.

Pierwszym wizytatorem klasztorów w diecezji kujawsko-kaliskiej z nominacji biskupa Marszewskiego został ks. kanonik Józef Rzewuski, który 25 lipca 1866 został ponadto mianowany częstochowskim proboszczem i dziekanem. Kapłan ten nie zdobył sobie wdzięcznej pamięci u paulinów. Został on określony mianem „szczególnie okrutnego niszczyciela klasztoru i jego suwerenności”. To on rzekomo „rozwiązał nowicjat, zwolnił kleryków ze ślubów, powstrzymał napływ nowych powołań, obostrzył kontakty z wiernymi” ${ }^{19}$. Taka ocena wizytatora

${ }^{16}$ Są to oryginały lub kopie korespondencji, która była do wizytatorów przysyłana przez rządców diecezji, konsystorze, kancelarię biskupią, przeorów i innych zakonników z Jasnej Góry oraz inne osoby, ale w ścisłym związku z Jasną Górą. Jest to wspomniana wcześniej teczka V 21 - Paulini.

${ }^{17}$ Archiwum to zawiera kilkadziesiąt poszytów, dotyczących spraw kościelnych w Częstochowie w okresie po powstaniu styczniowym. Por. Archiwum Państwowe w Częstochowie (dalej: APCz), Akta miasta Częstochowy; Materiał ten został zbadany przeze mnie i przygotowany do publikacji w roczniku Polskiego Towarzystwa Historycznego Oddział w Częstochowie: „Częstochowskie Teki Historyczne” pt. „Dokumenty magistratu miasta Częstochowy dotyczace Kościoła katolickiego z lat 1869-1914 w Archiwum Państwowym w Częstochowie".

${ }^{18}$ Naczelnik powiatu indagował w takiej sprawie wizytatora ks. Rzewuskiego w stosunku do zmarłego zakonnika Szczerbińskiego. Por. ADWł, V 21 - Paulini, Naczelnik powiatu do Wizytatora 6/18 XII 1868.

${ }^{19}$ Por. Zbudniewek, Konwent paulinów jasnogórskich, s. 27-38. 
rzuca cień i na biskupa Jana Michała Marszewskiego ${ }^{20}$, który danego kapłana na takie stanowisko desygnował. Powyżej wykazaliśmy, że każdy duchowny, pragnący pracować dla Kościoła, musiał się liczyć z zarządzeniami władz, i nie mógł jawnie przeciw nim wystąpić. Mógł natomiast, w ramach możliwości, ratować to, co było możliwe.

Ksiądz dziekan częstochowski J. Rzewuski jako wizytator klasztorów systematycznie przeprowadzał wizytacje we wszystkich istniejących jeszcze w diecezji konwentach zakonnych, w tym także w klasztorze jasnogórskim. Komunikował im decyzje władz państwowych, które kierowane były na ogół pod adresem rządcy diecezji. Poinformował on np. paulinów o tym, że chociaż bp Marszewski wielokrotnie przekazywał władzom Królestwa Polskiego ich prośby o pozwolenie na wyjazd $\mathrm{z}$ klasztoru poza miasto w celu zakupu żywności, to jednak stale otrzymywał odpowiedź negatywną. Ta informacja wizytatora Rzewuskiego została współcześnie zinterpretowana, jako akt wrogości samego ks. Rzewuskiego ${ }^{21}$. Kapłan ten pozostał na stanowisku wizytatora klasztorów także i po śmierci bpa Marszewskiego, gdy diecezją administrował ks. prałat Klemens Skupieński²2

Gdy 6 sierpnia 1867 r. ks. Rzewuski przybył na wizytację do klasztoru jasnogórskiego, zastał tam 30 zakonników. Nieobecnych było wówczas 8 paulinów, którzy za zezwoleniem władz państwowych byli na wyjeździe. Według oceny wizytatora księgi rachunkowe były dobrze prowadzone, a ogólny stan klasztoru był zadowalający. Można uogólniając powiedzieć, że inne jego protokoły wizytacyjne utrzymane są w podobnym tonie. Tak więc starał się on raczej wytłumaczyć zakonników, niż znaleźć powód do ich oskarżenia ${ }^{23}$.

Częstym tematem korespondencji pomiędzy klasztorem jasnogórskim a wizytatorem, oraz wizytatorem $\mathrm{i}$ administratorem diecezji było powiadamianie o śmierci kolejnych ojców paulinów ${ }^{24}$. Jest to rzeczą zrozumiałą, ponieważ młodsi „ponadetatowi" ojcowie paulini zostali skierowani do parafii, a zgromadzeni na Jasnej Górze przez władze carskie starzy ojcowie dożywali swoich dni w klasztorze $^{25}$

W czasie rządów diecezją kujawsko-kaliską prałata Skupieńskiego władze państwowe przeprowadziły w jasnogórskim klasztorze śledztwo. W efekcie został

${ }^{20}$ Marszewski Jan Michał (1800-1867). Wyświęcony na kapłana w 1823 r., administrator diecezji kujawsko-kaliskiej w latach 1850-1856, potem do śmierci ordynariusz kujawsko-kaliski, wyświęcony na biskupa w 1857 r.

${ }^{21}$ Por. dokument opublikowany w pracy: J. Zbudniewek, Jasna Góra w okresie niewoli narodowej, w: Częstochowa. Dzieje miasta i klasztoru jasnogórskiego, t. 2 - Wokresie niewoli 17931918, red. R. Kołodziejczyk, Częstochowa 2005, s. 79. Pochodzi on prawdopodobnie z AJG.

${ }^{22}$ Ks. Skupieński Klemens. 9 IX 1867 r. został po śmierci bpa Marszewskiego wybrany na wikariusza kapitulnego diecezji kujawsko-kaliskiej. Zmarł 3 X 1873 r.

${ }^{23}$ Por. ADWł, V 21 - Paulini, Protokół wizytacji klasztoru jasnogórskiego z 6 VIII 1867 r., napisany przez ks. Rzewuskiego i podpisany przez przeora o. Aleksandra Ziębę.

24 Dokładne dane, co do ilości zakonników w klasztorze, były potrzebne władzom do sporządzania listy uprawnionych do otrzymania pensji.

${ }^{25}$ Wiele tego typu dokumentów znajdujemy w wielokrotnie cytowanej tu teczce, dotyczącej Jasnej Góry, znajdującej się w ADWł, V 21 - Paulini. 
oskarżony o. Bonawentura Gawełczyk, który według ocen rewidujących, wyróżniał się „fanatycznym i niebezpiecznym dla rządu kierunkiem” i „lekko zdobywał wpływ na współbraci"26. Władze państwowe, chcąc pozbyć się o. Bonawentury z klasztoru, zaproponowały mu objęcie wiejskiej parafii, lecz on odmówił, tłumacząc, że wstąpił do klasztoru, aby pozostać w nim do śmierci ${ }^{27}$. Bez rozprawy sądowej i możliwości obrony został on uwięziony i odwieziony do Warszawy. Zarządzający wtedy diecezją kujawsko-kaliską ks. Skupieński oraz przeor jasnogórski o. Aleksander Zięba próbowali bronić o. Bonawenturę, za co sami zostali upomniani. Decyzję o skierowaniu o. Gawełczyka na zesłanie podjął namiestnik Królestwa Polskiego hr. Fiodor Fiodorowicz von Berg ${ }^{28}$. Oprócz o. Bonawentury wydalono wtedy z Jasnej Góry jeszcze 2 innych ojców ${ }^{29}$.

Za faktyczne lub domniemane przewinienia zakonników upominany był wizytator. Naczelnik powiatu częstochowskiego indagował wizytatora np. w sprawie rzekomo wrogiego wobec władz rządowych zachowania ojca Justusa Prawdowskiego, zakrystiana na Jasnej Górze, który uprzedzał pielgrzymów pragnących zwiedzać skarbiec słowami: „nie ma co patrzeć, wszystko opieczętowane”30. O wielu przenosinach zakonników nie decydował wizytator czy nawet administrator diecezji, lecz zarządzający sprawami duchownymi w rządzie Królestwa Polskiego urzędnik lub nawet ministerstwo spraw wewnętrznych. Tak było np. w wypadku przeniesienia o. Laurentego Kubaczka z Jasnej Góry do klasztoru św. Barbary $^{31}$.

9/20 grudnia 1869 r. ks. wizytator Rzewuski odbył kolejną przepisaną przez władze wizytację w klasztorze jasnogórskim. W protokole umieścił wszystkie 31 nazwisk zakonników obecnych w klasztorze. Nie indagował zakonników w sprawie, czy są oni zadowoleni z zarządu klasztorem, gdyż sprawa ta była stawiana niedawno w czasie obecności w klasztorze Administratora diecezji, kiedy to wobec skarg zakonników dotychczasowy przeor o. Aleksander Zięba złożył rezygna$\mathrm{cję}^{32}$. Jednak na liście zakonników jako przełożony figuruje jeszcze o. Zięba. To on powiadomił wizytatora, że poprzedniego dnia czyli 8 grudnia 1869 r. zmarł w klasztorze o. Jerzy Miczkiewicz. Wizytator zaraz następnego dnia zgłosił to administratorowi diecezji.

Chociaż zakonników w klasztorze ubywało, to i tak nie wszyscy mieli wypłacaną należną zapomogę, gdyż środki były wydzielane przez władze tylko na 24

${ }^{26}$ Por. Akta rządu carskiego, dotyczące Jasnej Góry z lat 1868-1914. Dokumenty zebrała i thumaczyła Julia Godlewska, wstępem i komentarzem opatrzył Janusz Zbudniewek ZP, SC 18 (1998), (dalej: Akta rzadu carskiego, SC, 18 [ROK]), s. 337-338 - Pismo hr. Berga do Wałujewa.

${ }^{27}$ AJG 740 - Droga i smutna pamiątka, 1869-1874, s. 1-2 - Zarządzający sprawami duchownymi w Królestwie Polskim do Administratora diecezji kujawsko-kaliskiej 11/23 IV 1868.

${ }^{28}$ Von Berg Fiodor Fiorodowicz (1794-1874). Namiestnik Królestwa Polskiego w latach 1863 -1874 .

${ }^{29}$ Por. AJG 740, s. 7-10 - Do zarządzającego sprawami religijnymi w Królestwie Polskim 4 VII 1870.

${ }^{30}$ Por. ADWł, V 21 - Paulini, Naczelnik powiatu do wizytatora i przeora 19 VIII 186[8].

${ }^{31}$ ADWł, V 21 - Paulini, Skupieński do Wizytatora 6 II 1869.

${ }^{32}$ ADWł, V 21 - Paulini, [Protokół z wizytacji] 9/20 XII 1869. 
osoby. Ks. Rzewuski informował o tym administratora diecezji. Domagał się np. rozwiązania kwestii zapomogi dla niedołężnego już zakonnika, który wcześniej został skierowany jako duszpasterz do diecezji kieleckiej, a jako niezdolny do pracy powrócił na Jasną Górę bez prawa do pensji. Przełożonym klasztorów przypominał, aby zapisywali na swoje listy tych kapłanów zakonnych, którzy dotychczas pracowali w diecezji, lecz zostali z parafii odwołani i zwróceni klasztorom ${ }^{33}$. Chodzi niewątpliwie o to, aby zakonnicy ci mogli pobierać pensje. Wizytator wstawiał się też za uwięzionego o. Bonawenturę Gawełczyka, zaświadczając, że był on zawsze lojalny wobec władz państwowych.

Ks. Rzewuski wizytował też Jasną Górę 7/19 października 1871 r. W klasztorze było wtedy 29 paulinów. Nie było nieporozumień ani pretensji u zakonników $^{34}$. Ks. Rzewuski wstawił się wtedy za chorego ojca Florentego Łakotę, który bezskutecznie leczył się od wielu lat w różnych miejscach. Ponieważ lekarze poradzili mu zamieszkać w domu drewnianym, ks. Rzewuski w październiku 1871 r. poprosił administratora diecezji o wyjednanie choremu paszportu na cały rok do Włodowca w powiecie będzińskim, gdzie przebywałby pod opieką rodziny ${ }^{35}$.

Gdy chory zakonnik pragnął wyjechać na leczenie poza klasztor, zdobywał najpierw pozwolenie przełożonego oraz odpowiednie świadectwo lekarskie o konieczności wyjazdu na leczenie np. do wód. Przeor lub sam zakonnik przekazywał tę sprawę wizytatorowi, a ten - administratorowi diecezji. Ten z kolei występował do odpowiednich władz, prosząc o zgodę na wydanie danemu zakonnikowi paszportu zagranicznego lub krajowego. O decyzji władz rządca diecezji zawiadamiał przeora. Natomiast drogą oficjalną przez gubernatora decyzja ta była przekazywana do naczelnika powiatu. Np. 20 VIII 1868 Administrator diecezji zawiadamiał wizytatora, że wystąpienie o pozwolenie na paszporty dla dwu zakonników z Jasnej Góry zostało skierowane do odpowiednich władz ${ }^{36}$. Podobnych spraw ks. Rzewuski jako wizytator załatwiał bardzo dużo.

Gdy generał-gubernator wydał pozwolenie na wyjazd zakonnika z klasztoru, jego urząd zawiadamiał o tym gubernatora piotrkowskiego, a ten polecał naczelnikowi powiatu częstochowskiego wydać paszport danemu duchownemu ${ }^{37}$. Informowana była także kancelaria biskupa, i dlatego stamtąd też przychodziły powiadomienia ${ }^{38}$.

Czasem klasztor otrzymywał pewną zapomogę od naczelnika powiatu częstochowskiego.Przeoro.Laurenty Kubaczekpoinformowałnp.ks. Rzewuskiegootym, że zasiłek otrzymany z kasy powiatu rozdzielił on w równej mierze pomiędzy

${ }^{33}$ ADW1, V 21 - Paulini, Por. np. list ks. Skupniewskiego do ks. Rzewuskiego z 4 X 1871.

${ }^{34}$ ADWł, V 21 - Paulini, Protokół z 7/19 X 1871 r.

${ }^{35}$ ADWł, V 21 - Paulini, Łakota do Administratora diecezji 1 X 1871.

${ }^{36}$ ADW, V 21 - Paulini.

${ }^{37}$ AJG 2205, o. Euzebiusz Rejman, s. 151 - Kancelariâ kujawsko-kališskiego episkopa Rejmanu 2/14 XII 1894.

${ }^{38}$ AJG 2205, o. Euzebiusz Rejman, s. 159 - Kancelariâ kuâwsko-kališskiego episkopa Rejmanu 7/19 XII 1894. 
wszystkich 29 zakonników. Każdy zakonnik otrzymał wtedy po 3 ruble 98 i pół kop. ${ }^{39}$.

Wśród korespondencji pomiędzy wizytatorem, zarządem klasztoru jasnogórskiego i administratorem diecezji nie znajdujemy potwierdzenia jakichś nieporozumień między ks. Rzewuskim i zakonnikami. Jedynym listem, w którym ks. wizytator poskarżył się na przeora (o. Laurentego Kubaczka), jest informacja o tym, że wizytator długo cierpliwie znosił nieżyczliwość „Przełożonego”. Rzewuski pisał zawsze nazwanie tej godności z dużej litery, podczas gdy w pismach do administratora diecezji jego funkcję wymieniał zazwyczaj w skrócie, (np. Adm. Dyec.) nie podając ani jego nazwiska, ani godności adresata. W sprawozdaniu z 18/30 sierpnia 1873 r. z przeprowadzonej wizytacji na Jasnej Górze, pochwalił gospodarność przełożonego i zachęcał zakonników do wzajemnego wybaczania sobie $\operatorname{win}^{40}$.

Innym zadaniem wizytatora było instalowanie zakonników na stanowiskach kościelnych i zdawanie z tego sprawy administratorowi diecezji oraz naczelnikowi powiatu częstochowskiego. Należało wtedy sprawdzić stan inwentarza parafii. W wypadku braku odpowiedniej księgi musiał on zrobić spis inwentarza i napisać protokół z odbytej uroczystości ${ }^{41}$.

Ks. Rzewuski pozostał na stanowisku wizytatora klasztorów także w czasie urzędowania nowego wikariusza kapitulnego ks. Floriana Kosińskiego ${ }^{42}$ po śmierci prałata Skupieńskiego, która nastąpiła 21 kwietnia 1873 r. $^{43}$, a także po objęciu w 1875 r. diecezji kujawsko-kaliskiej przez biskupa-zesłańca, Wincentego Chościak-Popiela. Ostatnim z dokumentów, napisanych przez ks. Rzewuskiego i umieszczonym w cytowanej przez nas teczce, dotyczącej Jasnej Góry, jest jego prośba z 2/14 maja 1877 r. skierowana do biskupa Popiela o wyjednanie paszportu dla o. Januarego Witkowskiego ${ }^{44}$.

Po śmierci ks. Rzewuskiego 28 stycznia 1878 r. nowym proboszczem i dziekanem częstochowskim został dotychczasowy profesor seminarium duchownego

${ }^{39}$ ADW1, V 21 - Paulini, Kubaczek do Rzewuskiego 29 XII 1871, Lista z podpisami.

${ }^{40}$ ADW1, V 21 - Paulini, [Protokół wizytacji] Rzewuski i Kubaczek 18/30 VIII 1873.

${ }^{41}$ ADWt, V 21 - Paulini, Por. np. List administratora diecezji kujawsko-kaliskiej ks. prałata Skupieńskiego do wizytatora i dziekana ks. kan. Rzewuskiego z 16 II 1867 r., o naznaczeniu do Kostomłotjako wikariusza o. Rajmunda Cholewińskiego. Ks. Rzewuski stwierdził, żew Kostomłotach nie było inwentarza przynależności kościelnych i osobiście taki inwentarz sporządził oraz napisał protokół. Tamże, por. [Protokół] z dn. 26 III 1868.

${ }^{42}$ Władze państwowe zadbały, aby nowy Administrator nie został wybrany od razu po pogrzebie ks. Skupieńskiego, który odbywał się w Piotrkowie, lecz aby wybory nastąpiły we Włocławku. Gubernator warszawski starał się wpłynąć na kapitułę, aby wybrała bądź ks. Szulca, bądź ks. Kosińskiego, ponieważ byli oni uważani za odpowiednich, aby interesy państwowe były zabezpieczone. Kapituła wybrała 26 IV 1873 r. ks. Kosińskiego. Por. RGIA, F. 821, op. 1, d. 1218 - Delo ob. utverždenii ks. Skupenskogo, 1. 15-18.

${ }^{43}$ Por. RGIA, F. 821, op. 1, d. 1218 - Delo ob. utverždenii ks. Skupenskogo administratorom kuj.-kališskoj eparhii, 1. 12.

${ }^{44}$ Por. ADWł, V 21 - Paulini, ks. January Witkowski do wizytatora 2 V 1877, Rzewuski do Popiela 2/14 V 1877. 
we Włocławku, ks. Mikołaj Nowakowski ${ }^{45}$. Nie wypełniał on obowiązków wizytatora klasztorów, dlatego jego relacje z paulinami były dobre.

Wizytatorem został ks. kan. Józef Kozłowski po objęciu stanowiska wizytatora postanowił sprawdzić księgi przychodów i rozchodów na Jasnej Górze ${ }^{46}$. Z racji swojego urzędu był obecny przy składaniu ślubów wieczystych przez ojca Józefa Jodela ${ }^{47}$. Prawdopodobnie na jego polecenie spisano wtedy listę 21 zakonników pozostających w klasztorze. Przy każdym nazwisku podano rok urodzenia zakonnika, rok wstąpienia do klasztoru, profesji, święceń kapłańskich i rok objęcia ostatniego urzędu. Dwa nazwiska: jednego kapłana i jednego nowicjusza zostały przekreślone, co oznacza, że kapłan zmarł, a nowicjusz odszedł po spisaniu listy. Na liście tej znajduje się też jeden brat zakonny oraz dwaj kanonicy laterańscy, którzy zostali prawdopodobnie przeniesieni na Jasną Górę w związku z likwidacją ich klasztoru ${ }^{48}$.

Ks. Kozłowski nie zamieszkiwał w Częstochowie, lecz we Włocławku. Korespondencja między przeorem i wizytatorem odbywała się drogą pocztową. Wizytator Kozłowski pośredniczył w załatwianiu przez biskupa paulinom pozwoleń na wyjazd z klasztoru. Biskup zwracał się do urzędu generał gubernatora i po otrzymaniu odpowiedzi często sam pisał do wizytatora. Takich odpowiedzi spotykamy wiele w latach 1879, 1880 i 1881.

Kozłowski, podobnie, jak i jego poprzednik, starał się o pozwolenie dla chorych zakonników na wyjazd celem leczenia oraz próbował pomóc w poprawie życia w klasztorze. Sam przeor o. Kubaczek 16 czerwca 1879 r. poinformował wizytatora, że wobec nadszarpniętego zdrowia powinien wyjechać na leczenie do Goczałkowic Zdroju ${ }^{49}$. I jemu wizytator załatwił pozwolenie na opuszczenie klasztoru.

Gdy bp Popiel dowiedział się o planowanej przez władze rewizji w klasztorze, wysłał też na Jasną Górę wizytatora ks. Kozłowskiego. Ten nie stwierdził jednak naruszeń w rachunkowości ${ }^{50}$. Tymczasem władze guberni piotrkowskiej zwróciły uwagę na coś innego: brakowało ubikacji wokół klasztoru, dlatego liczni pielgrzymi załatwiali swoje potrzeby gdzie popadło, co prowadziło do zagrożenia epidemią. Gubernator 23 czerwca 1879 r. polecił tę sprawę rozwiązać wizytatorowi klasztorów ${ }^{51}$.

Gdy 20 listopada $1881 \mathrm{r}$. warszawski generał-gubernator zatwierdził o. Kubarskiego na stanowisku przeora Jasnej Góry, wizytator ks. Kozłowski otrzymał polecenie, aby przeprowadził jego instalację i przy okazji skontrolował księgi ra-

${ }^{45} 12 / 24$ X 1878 r. gubernator doniósł ministrowi spraw wewnętrznych o szczególnej roli, jaką w zorganizowaniu powitania bpa Popiela odegrał ks. Nowakowski. Por. Akta rządu carskiego, „St. Clar." 18, [ROK] s. 252.

${ }^{46}$ ADWł, V 21 - Paulini, Ks. J. Kozłowski 22 grudnia 1879 r./3 stycznia 1880 r.

${ }^{47}$ Por. ADW1, V 21 - Paulini, Protokół napisany przez Kozłowskiego i podpisany przez przeora Kubaczka 22 XII 1879/3 I 1880.

${ }^{48}$ ADWł, V 21 - Paulini, Lista księży i nowicjuszów.

${ }^{49}$ ADW1, V 21 - Paulini, Kubaczek do wizytatora 16 X 1879.

${ }^{50}$ ADWł, V 21 - Paulini, Kozłowski do Popiela 18 IX 1879.

${ }^{51}$ ADWł, V 21 - Paulini, Gubernator do wizytatora 23 VI 1879. 
chunkowe klasztoru. Uczynił to 7 grudnia $1881 \mathrm{r}^{52}$. Protokół, jaki przy tej okazji napisał, pośrednio świadczy o tym, że o. Kubaczek jako przeor był niezłym gospodarzem i pozostawił klasztor swojemu następcy w dobrym stanie materialnym. Ks. Kozłowski wezwał nowego przełożonego do troski o karność zakonną i o nowicjat $^{53}$.

W połowie 1880 r. roku ks. Kozłowski odbył na Jasnej Górze kolejną nakazaną przez prawo państwowe wizytację. Wizytacja ta polegała m. in. na zapoznaniu się z księgą przychodów i rozchodów ${ }^{54}$. Podobny protokół napisał wizytator podczas wizytacji 20 III/1 IV 1882 r. Dotychczasowy przeor Jasnej Góry o. Laurenty Kubaczek, został wysłany jako duszpasterz do kościoła św. Barbary ${ }^{55}$. Wizytator musiał wspólnie z o. Kubaczkiem przejrzeć inwentarz tego kościoła ${ }^{56}$. Ks. wizytator Kozłowski regularnie wizytował klasztor jasnogórski. Protokół wizytacji z 20 marca /1 kwietnia 1882 r. podpisał także przeor o. Piotr Kubarski. Paulini byli zadowoleni z nowego zarządu klasztoru ${ }^{57}$.

W 1882 r. w jasnogórskim klasztorze zmarło kilku ojców: 21 sierpnia Stanisław Kopiczyński w wieku 62 lat, 29 września Henryk Klimesz w wieku 82 lat, a 7 października o. Franciszek Pluciński w wieku 64 lat ${ }^{58}$. Przeor Kubarski skarżył się wizytatorowi na ciężar swojego obowiązku. Na Jasnej Górze nadal nie było wystarczającej liczby ojców. Aby zaradzić potrzebom duszpasterskim, przyjmowano na mieszkanie w klasztorze niektórych skompromitowanych kapłanów diecezjalnych. Zgryzot dostarczali także niektórzy świeccy pracownicy, walcząc o swoje prawa na drodze sądowej. Przeor próbował więc rozwiązać problemy zgodnie ze wskazówkami wizytatora ${ }^{59}$.

Przeor Kubarski poinformował wizytatora o środkach, jakie zostały zastosowane w stosunku do zakonników, którzy zawinili przeciw karności zakonnej ${ }^{60}$. Uskarżał się też na niemożliwość odzyskania kapitałów, zapisanych klasztorowi w przeszłości przez dobrodziejów. Nie pomógł gubernator piotrkowski. Ponieważ sprawa została przekazana do decyzji generał-gubernatora, przełożony błagał biskupa Bereśniewicza, aby ten wstawił się u władz, gdyż kapitały te potrzebne byłyby na odbudowę niszczących się murów, okalających klasztor ${ }^{61}$.

O. Bonawentura Gawełczyk po prawie dwudziestu latach zesłania 23 II/ 7 III 1885 r. powrócił na Jasną Górę ${ }^{62}$ i podjął się tam gorliwej pracy. Ponieważ jego zdrowie zostało nadszarpnięte, $w$ klasztorze nie było odpowiednich warunków do odpoczynku i leczenia, starał się więc przez wizytatora o pozwolenie na wyjazd

\footnotetext{
${ }^{52}$ ADW1, V 21 - Paulini, Biskup Popiel do wizytatora 5 XII 1881.

${ }^{53}$ ADWł, V 21 - Paulini, Protokół z dn. 27 XI/7 XII 1881.

${ }^{54}$ ADWł, V 21 - Paulini, Protokół wizytacji z 29 VII/10 VIII 1880 r.

${ }^{55}$ ADW1, V 21 - Paulini, Wizytator do biskupa 9 XII 1881.

${ }^{56}$ ADW1, V 21 - Paulini, Biskup Popiel do wizytatora 10 XII 1881.

${ }^{57}$ ADWł, V 21 - Paulini, Protokół wizytacji z 20 III/10 V 1882 r.

${ }^{58}$ ADWł, V 21 - Paulini, Kubarski do Wizytatora 21 VIII, 30 IX i 9 X 1882.

${ }^{59}$ ADWł, V 21 - Paulini, Kubarski do wizytatora 15 III 1883.

${ }^{60}$ ADWł, V 21 - Paulini, Kubarski do wizytatora 2? IX 1883.

${ }^{61}$ ADWł, V 21 - Paulini, Kubarski do wizytatora 22 I 1884.

${ }^{62}$ AJG 740 - Droga i smutna pamiątka..., s. 69.
} 
do sanatorium ${ }^{63}$. Władze, wydając paulinowi paszport, postawiły jednak warunek, aby o. Gawełczyk, jadąc do Ciechocinka, wysiadł w Skierniewicach, by ominąć Warszawę ${ }^{64}$.

Zarówno biskup jak i wizytator musieli poświęcać wiele wysiłku, aby przekazana przez jakiegoś dobrodzieja ofiara mogła być przekazana klasztorowi. Tak było np. z ofiarą 1500 rubli, zapisaną na rzecz klasztoru przez Paulinę Piasecką ${ }^{65}$. Niezbyt przyjemnym obowiązkiem wizytatora było zbadanie sprawy mieszkającego na Jasnej Górze jednego z dwóch kanoników regularnych, Królikowskiego, który okazał się alkoholikiem. Według informacji, które przeor przekazał wizytatorowi, ks. kanonik był człowiekiem gorliwym, pracowitym, interesującym się literaturą religijną, gospodarnym, lecz kilka razy w roku wpadającym na okres dwóch tygodni w „ciąg” alkoholowy. Wtedy nie był zdolny do pracy. Poza tymi okresami gorliwie pomagał na Jasnej Górze ${ }^{66}$.

Bp Bereśniewicz pragnął na Jasnej Górze przeprowadzić reformy, zobowiązał więc wizytatora, aby ten dobrze zorientował się w problemach wspólnoty i sprawach materialnych zakonników. Ks. Kozłowski zbadał sprawę i poinformował ordynariusza, że przed kasatą księża-paulini na Jasnej Górze byli zobowiązani do odprawiania 4 mszy św. w tygodniu, pozostawiając ofiarę na klasztor, a za pozostałe 3 msze św. otrzymywali po 7 zł 15 gr. W klasztorze mieli zapewnione tylko dwa posiłki: obiad i kolację, musieli więc dokupować żywność. Po kasacie, w czasie kadencji przeora Zięby, wszystkie ofiary na odprawiane msze św. zakonnicy brali sobie, lecz ponieważ nadal czuli się pokrzywdzeni, przeor polecił wypłacać im po 60 rubli rocznie, za co mieli jednak odprawiać 25 mszy św. za dobrodziejów. Przeor Kubarski stwierdzał jednak, że ojcowie nie spełniali obowiązku odprawiania tych Mszy świętych. Na Jasnej Górze istniał zwyczaj wprowadzania pielgrzymek przez ojców, za co otrzymywali oni przeciętnie po ok. 6 rubli. Ponieważ po kasacie zakonnicy mieli zapewnione też śniadanie, przeor postanowił całkowicie wstrzymać wypłacanie zakonnikom owych 60 rubli lub choćby zmniejszyć tę sumę.

Wizytator stwierdził, że najwięcej zakonnicy mogą „zarobić” przy wprowadzaniu pielgrzymek, a także przy wpisywaniu wiernych do bractw. Niektórzy zakonnicy, należący do grupy 4 kaznodziejów otrzymywali też pewne wynagrodzenie. Przeor stwierdził więc, że każdy zakonnik może mieć ok. 500 rubli rocznego dochodu, a niektórzy nawet 800 rubli. W takiej sytuacji, proponował nie wypłacać zakonnikom po 60 rubli, lecz najwyżej po 30 rubli, lecz po zobowiązaniu ich do odprawiania 12 mszy św. za dobrodziejów.

Po zrelacjonowaniu myśli przeora Kubarskiego ks. wizytator przedstawił biskupowi własny pogląd na sprawę utrzymania zakonników. Stwierdził, że ze

${ }^{63}$ AJG 1486 - Personalia paulinów 1845-1909.

${ }^{64}$ Jeśli główny Naczelnik kraju, czyli warszawski generał-gubernator wydał pozwolenie na wydanie paszportu, to po szczeblach hierarchii administracyjnej i policyjnej docierało ono do powiatu, a wtedy naczelnik lub policmajster wysyłał zawiadomienie do przeora klasztoru. Por. AJG 1486 - Parsonalia paulinów 1845-1909, s. 505-688.

${ }^{65}$ ADWł, V 21 - Paulini, Korespondencja 21 II, w III 1885, 11 III i 16 III, 7 IV 1885.

${ }^{66}$ ADW1, V 21 - Paulini, Kubarski do wizytatora 21 V 1885. 
względu na zbyt słabe jedzenie w klasztorze, nie należy zmuszać zakonników do odprawiania darmowych mszy św. Zlikwidowanie zasiłku wg wizytatora mogłoby być możliwe dopiero po wprowadzeniu zmian w ekonomii klasztoru. Podkreślił bowiem, że w klasztorze brak jest opieki zdrowotnej, ojcowie zmuszeni są utrzymywać służących. Gdyby została przeprowadzona reforma, ustąpiłyby powody do narzekań i poprawiłaby się karność zakonna.

Jednak, jak zauważył wizytator, obecny przeor nie ma ani czasu, ani odpowiedniej zdolności do wprowadzenia takich zmian, a wikariusz jest bardzo zajęty w zakrystii. Zaproponował więc, aby zarząd sprawami ekonomicznych (kuchnia, refektarz, troska o potrzeby zakonników i porządek w klasztorze) powierzyć jednemu z młodszych zakonników. Jako energicznego i mającego odpowiednie zdolności wskazał o. Bonawenturę Gawełczyka. Taki ekonom powinien troszczyć się nie tylko o potrzeby zakonników, lecz także o księży, przybywających na Jasną Górę do pomocy lub też z powodu swoich potrzeb duchowych ${ }^{67}$.

$\mathrm{W}$ odpowiedzi na tej raport biskup Bereśniewicz przesłał wizytatorowi swoją odezwę, w której zostały uwzględnione wszystkie propozycje wizytatora, łącznie z naznaczeniem o. Bonawentury. Ks. Kozłowski przywiózł tę odezwę do klasztoru i 2 stycznia 1886 r. ogłosił paulinom ${ }^{68}$. Ks. wizytator zaproponował zwolnić o. Ferencewicza z obowiązku prokuratora klasztoru i naznaczyć na to stanowisko o. Euzebiusza Rejmana. Bp Bereśniewicz po uprzednim uzyskaniu zgody na to od generał-gubernatora, tak rzeczywiście postąpił ${ }^{69}$. Wtedy ks. Kozłowski przybył ponownie do klasztoru i ogłosił te decyzje $\mathrm{e}^{70}$.

Wizytator zaproponował też inne formy zaprowadzenia porządku na Jasnej Górze. Jeśli chodzi o sprawę słuchania spowiedzi zaproponował ponumerowanie konfesjonałów i wprowadzenie stałych dyżurów dla wszystkich ojców. Ze względu na przeciążenie zakrystiana, podpowiadał, aby znaczną część jego obowiązków przełożyć na świeżo nominowanego prokuratora. Do niego należałaby więc troska o porządek w kościele, troska o zachowanie czystości obrazów i dywanów, naczyń liturgicznych, lawaba, ampułek, reperacji i przewietrzania bielizny i odzieży liturgicznej, oraz zatroszczenie o składane przez wiernych ofiary w postaci tkanin.

Wizytator radził też, aby na nowego prokuratora przełożyć nadzór nad służbą kościelną, dając mu prawo upominania i ewentualnego zwalniania jej. Wizytator zaproponował, aby pielgrzymki były wprowadzane przez wszystkich zakonników po kolei, zgodnie z grafikiem. Taki dyżur trwałby pół dnia, w innym czasie zakonnik powinien spowiadać. Chodziło prawdopodobnie o to, aby ukrócić praktykę polegającą na tym, że jedni kapłani prześcigali się we wprowadzaniu pielgrzymek, co wiązało się z otrzymaniem ofiary, a inni byli nadmiernie utrudzeni spowiedzią. Zaproponował ponadto, aby troskę o renovatio Sanctissimi włożyć na jednego z kapłanów ${ }^{71}$.

\footnotetext{
${ }^{67}$ ADWł, V 21 - Paulini, Wizytator do bpa Bereśniewicza 2 XII 1885.

${ }^{68}$ ADW1, V 21 - Paulini, Biskup Bereśniewicz do wizytatora 31 XII 1885.

${ }^{69}$ ADWł, V 21 - Paulini, Biskup Bereśniewicz do wizytatora 23 I 1886.

${ }^{70}$ ADWł, V 21 - Paulini, Protokół 23 II 1886.

${ }^{71}$ ADW1, V 21 - Paulini, Wizytator do biskupa Bereśniewicza 25 II 1886.
} 
Wiele problemów wynikało z konieczności zapisywania ofiar, proponowano nawet zrezygnować z ich przyjmowania. O. Rejman, który bardzo szybko wszedł w zakres swoich nowych obowiązków, 19 kwietnia 1886 r. informował już wizytatora, że nie można zlikwidować przyjmowania ofiar, ponieważ jest to powszechny zwyczaj ${ }^{72}$. Chociaż koniecznością jest zatrudnienie odpowiedniego pisarza, to jednak nie można zrezygnować z przyjmowania ofiar.

Biskup Bereśniewicz skorzystał z raportu wizytatora, dotyczącego porządków na Jasnej Górze. Aby niejako ochronić wizytatora, w swojej odezwie napisał, że decyzje podejmuje na podstawie własnego doświadczenia. Jak należy się domyślać, sam Biskup Bereśniewicz zauważył na Jasnej Górze szereg nieporządków w organizacji życia wspólnotowego, co prowadziło do mankamentów w służbie duszpasterskiej. Decyzje, podjęte przez biskupa były jeszcze bardziej szczegółowe, niż zaproponowane przez wizytatora ${ }^{73}$.

Wiele problemów, związanych z funkcjonowaniem Jasnej Góry musiał też rozwiązywać kolejny wizytator ks. Franciszek Stopierzyński. On też pośredniczył w załatwianiu pozwolenia na wyjazd z klasztoru dla zakonników, np. dla o. Leona Mokrskiego $^{74}$. Ten zakonnik będzie bardzo często starał się o wyjazd celem leczenia $^{75}$. Ks. stopierzyński dowiedział się o miejscu pobytu o. Piusa Przeździeckiego na zesłaniu. Było to miasto Insar w penzeńskiej guberni, w domu Czumakowa przy ulicy Sołdatskiej ${ }^{76}$. Korespondencja wizytatora ks. Stopierzyńskiego mówi o sprawach, jakimi żyła Jasna Góra pod koniec XIX w. Największą część tej korespondencji zajmują sprawy pośredniczenia w załatwianiu wyjazdów paulinów poza Częstochowę. Nawet ta korespondencja pokazuje różne charaktery poszczególnych zakonników. Zrozumiałą jest rzeczą, że najczęstszym korespondentem wizytatora z Jasnej Góry był przeor Rejman.

Bardzo często do ks. wizytatora Stopierzyńskiego pisał o. Marian Piotrowski, który wstąpił do klasztoru jako kapłan, lecz będąc prawdopodobnie skrupulatem, martwił się tym, że na Jasnej Górze nie jest należycie wykorzystany. O. Rejman go rozumiał. Zgodził się np. na jego wyjazd do kolegi proboszcz, mając nadzieję, że wzmocni to jego tęsknotę za Jasną Górą. Przeor widział, że o. Piotrowski jest nerwowy i ciągle zmienia swoje zdanie ${ }^{77}$. Ks. Piotrowski zgodził się na pracę w innym klasztorze lub na parafii. Kiedy jednak w końcu został kapelanem domu starców w Kaliszu, wolał się upewnić, czy powinien działać jako paulin czy jako kapłan diecezjalny ${ }^{78}$.

${ }^{72}$ Problem polegał na tym, że władze państwowe żądały zapisywania każdej ofiary, co bardzo mocno angażowało paulinów.

${ }^{73}$ ADW1, V 21 - Paulini, Biskup Bereśniewicz do wizytatora 26 II 1886.

${ }^{74}$ ADWł, V 21 - Paulini, Mokrski do Stopierzyńskiego 11 X 1895.

${ }^{75}$ ADWł, V 21 - Paulini, Mokrski do wizytatora Stopierzyńskiego ? II 1892.

${ }^{76}$ ADW1, V 21 - Paulini, ks. Marian do Stopierzyńskiego 16/28 X 1895.

${ }^{77}$ ADWł, V 21 - Paulini, Rejman do Stopierzyńskiego 16 V 1896.

${ }^{78}$ ADWł, V 21 - Paulini, Piotrowski do Stopierzyńskiego 16 III 1897. 
Wizytator miał też wyjaśnić, czy kandydat Józef Olesiński-Matusiak, który otrzymał pozwolenie na wstąpienie do klasztoru od generał-gubernatora, w rzeczywistości przybył na Jasną Górę ${ }^{79}$.

Przeor Rejman, oprócz próśb do wizytatora o wyjednanie przez biskupa pozwolenia na osobiste wyjazdy, załatwiał także inne sprawy klasztoru, nieraz radził się lub informował wizytatora o problemach z innymi ojcami, z nowicjuszami, klerykami, uzgadniał terminy przyjazdu wizytatora do klasztoru, popierał petycje o pozwolenie na wyjazd zakonników. O. Rejman, zdając sobie sprawę z tego, że jakiś zakonnik nadużywa pozwolenia na wyjazd dla innych celów, podpisywał jego petycję, nie wyrażając sprzeciwu, lecz w piśmie do wizytatora wyjaśniał, jak sprawa wygląda, co chyba nie świadczy o sile jego charakteru.

Spośród innych zakonników, niektórzy wcale nie pisali do wizytatora, a inni z kolei pisali dość dużo, dając wyraz swoim przeżyciom, problemom, żalom. Korespondencja pokazuje, że zakonnik Mokrski prawdopodobnie nadużywał zezwoleń na leczenie się w Warszawie. Uzyskiwał zgodę na określony wyjazd, a potem zwracał się wprost do biskupa i załatwiał sobie przedłużenie pobytu w Warsza$w_{i e}^{80}$. Postępowaniem o. Mokrskiego niepokoiło o. Rejmana, czym dzielił się w listach do wizytatora. Nie był jednak w stanie osobiście zabronić zakonnikowi wyjazdu, dawał mu dobrą opinię, lecz w liście do wizytatora informował o rzeczywistym stanie sprawy ${ }^{81}$. Często starał się o wyjazd o. Romuald Dziemiadowicz. Treść jego korespondencji zdradza człowieka żywego, nieźle wykształconego, mającego przy tym świadomość swoich wad ${ }^{82}$.

Gdy biskup Bereśniewicz ciężko zachorował, wizytator przesłał na Jasną Górę prośby o msze św. i modlitwy w jego intencji, załączając stypendia. O. Rejman odpowiedział, że ojcowie modlili się już za biskupa, i nadal będą to czynić, także i wtedy, gdy nie otrzymają stypendium ${ }^{83}$.

Już w 1907 r. na Jasną Górę został skierowany jako apostolski wizytator o. Lamosz, karmelita, który kilkakrotnie przyjeżdżał i przeprowadzał kapituły. Dzięki zdecydowanej postawie o. Piusa Przeździeckiego, w obecności wizytatora został wybrany nowy przeor w osobie byłego kapłana diecezjalnego, o. Justyna Welońskiego. Jednak generał-gubernator warszawski nie uznał wyboru o. Welońskiego, i nie zgodził się na zwolnienie o. Rejmana $\mathrm{z}$ dotychczasowej funkcji ${ }^{84}$.

${ }^{79}$ ADW1, V 21 - Paulini, Kancelaria biskupa do Stopierzyńskiego 14/26 X 1895.

${ }^{80} 11$ X 1895 ks. Leon Mokrski zwrócił się do Stopierzyńskiego o pośrednictwo w załatwieniu paszportu na leczenie, załączając zaświadczenia lekarskie. Później już mamy jedynie informacje bpa Bereśniewicza, kierowane do wizytatora, że generał-gubernator pozwolił mu na przedłużenie pobytu. Por. ADWł, V 21, Paulini, Biskup Bereśniewicz do Stopierzyńskiego 3/15 XI 1995, 26 XII 1995/7 I 1996, 16/28 II 1996. 29 IV/4 V 1997 Mokrski prosił o 6-tygodniowy wyjazd do Buska.

${ }^{81}$ Por. np. ADWł, V 21 - Paulini, Paulini, Rejman do Stopierzyńskiego 29 III 1897.

${ }^{82}$ ADWł, V 21 - Paulini, Dziemiadowicz do Stopierzyńskiego 25 IV/7 V 1896, 25 XI 1896, 11 XII 1896.

${ }^{83}$ ADWł, V 21 - Paulini, Rejman do wizytatora 3 II 1896.

${ }^{84}$ AJG 2159, Wybory przeorów1796 - 1919, s. 41 - Načalnik č. uezda - nastoâtelu Rejmanu (?) VII 1910. 
Zażądał natomiast listy uczestników głosowania i jego wyników ${ }^{85}$. Sprawę tę przedstawimy dokładniej w trzecim rozdziale.

\section{Troska biskupów o powołania do zakonu paulinów.}

Troska biskupów kujawsko-kaliskich o Jasną Górę przejawiła się szczególnie wtedy, gdy liczba zakonników w klasztorze spadła poniżej 24 osób. Wielka śmiertelność starszych ojców, zwłaszcza z powodu fatalnych warunków zdrowotnych i przepracowania, mogłaby doprowadzić do stopniowego wymarcia klasztoru. Jak wcześniej stwierdziliśmy, wielu dotychczasowych ojców umierało stosunkowo młodo. Chociaż w końcu władze państwowe pozwoliły przyjmować nowych kandydatów, to jednak nie było łatwo przezwyciężyć kryzys powołań. Dodatkowym utrudnieniem był wymóg prawa rosyjskiego, aby przyjmować kandydatów dopiero po ukończeniu 24 lat, a śluby wieczyste przyjmować dopiero po ukończeniu 30 lat. Ponieważ przez ok. 25 lat nie było nowicjatu, ojcowie nie znali wymogów zarówno prawa kościelnego, jak i państwowego, dotyczącego nowicjuszy. Wśród kandydatów, którzy się wtedy pojawili, byli również kapłani diecezjalni.

Kandydaci w różny sposób zabiegali o przyjęcie do jasnogórskiego klasztoru. Jedni najpierw zwracali się do klasztoru jasnogórskiego. Po uzyskaniu obietnicy przyjęcia, zdobywali odpowiednie pozwolenie od władz państwowych. Inni z kolei od razu zwracali się wprost do władz państwowych, i uzyskawszy pozwolenie, kierowali się do klasztoru jasnogórskiego. Wtedy nie łatwo było im odmówić, choćby wszystkie racje przemawiały za niezdolnością kandydata do życia zakonnego. Klasztor musiał się jednak starać o otrzymanie dla każdego nowicjusza pensji rządowej.

O. Kubaczek zaproponował kształcić na kapłana jednego z kandydatów, Wincentego Malińskiego. Prosił więc ks. wizytatora Kozłowskiego, by wystarał się o środki finansowe na jego utrzymanie w seminarium. Sprawę tę mógł jednak załatwiać jedynie biskup ${ }^{86}$. Gdy przeor wyjechał na leczenie, korespondencję w tej sprawie kontynuował wikariusz o. Ptakowski. Na liście mieszkańców Jasnej Góry, którą przy tej okazji załączył widnieje już jedynie 20 nazwisk, przy tym są tam mieszkający w klasztorze dwaj kanonicy regularni, jeden brat zakonny, kleryk Maliński i, jako zarządca kościoła św. Barbary, o. Teodor Mochalski ${ }^{87}$.

Pozwolenie na przyjęcie kleryka Józefa (Wincentego) Malińskiego wydał gubernator piotrkowski 7 lipca 1878 r. ${ }^{88}$. Seminarium 20 września 1879 r. zawiadomiło klasztor o gotowości przyjęcia paulińskiego kandydata. Wtedy dopiero o. Ptakowski mógł zwrócić się do wizytatora o załatwienie klerykowi paszportu na przejazd do Włocławka, gdyż ten bez paszportu nie mógł opuścić klasztoru ${ }^{89}$. Władze zakonne postanowiły usunąć kleryka Malińskiego z powodu złego zachowania. On

\footnotetext{
${ }^{85}$ AJG 2159, Wybory przeorów, s. 39 - Načalnik č. uezda - nastoâtelu Rejmanu 15 VII 1910.

${ }^{86}$ ADWł, V 21 - Paulini, Kozłowski do bpa Popiela 26 IX 1879.

${ }^{87}$ ADW1, V 21 - Paulini, Ptakowski do wizytatora 20 IX 1879 (Lista).

${ }^{88}$ ADWł, V 21 - Paulini, Kubaczek do wizytatora 7 X 1879.

${ }^{89}$ ADWł, V 21 - Paulini, Ptakowski do wizytatora 20 IX 1879.
} 
zaczął wtedy rozgłaszać, że zostanie przyjęty do seminarium jako świecki kandydat. Uprzedzono więc władze seminaryjne, aby go nie przyjmowały ${ }^{90}$.

Problemem klasztoru był nie tylko brak kandydatów, lecz i wydalenie przyjętego nowicjusza, gdyby okazało się, że nie nadaje się na zakonnika. Przecież władze państwowe decydowały o przyjęciu do klasztoru. Wśród kandydatów, którzy się pojawili, i mieli pozwolenie rządowe, Leon Zenius okazał się chory umysłowo ${ }^{91}$, a były kleryk seminarium sejneńskiego Antoni Godlewski budził poważne wątpliwości ${ }^{92}$. Kandydatem, który został zaakceptowany zarówno przez przeora Kubaczka i biskupa Popiela, jak i gubernatora piotrkowskiego, był Józef Gromek $^{93}$. Kolejnymi kandydatami byli: urzędnik Jan Rejman z Wielunia oraz ks. Kłosiński z Bielin. O. Kubaczek obawiał się jednak, że powołanie zakonne tego drugiego było niezbyt autentyczne. Miał jednak nadzieję na to, że rząd nie dopuści do jego przyjęcia ${ }^{94}$. Kandydat J. Rejman, chociaż nie od razu, otrzymał państwową aprobatę, o czym sam biskup Popiel powiadomił wizytatora 30 listopada 1880 r. ${ }^{95}$. Przeor już 17 grudnia donosił wizytatorowi o jego obłóczynach w klasztorze. Po odbyciu przez Rejmana rocznego nowicjatu, przełożony zwrócił się przez pośrednictwo wizytatora do biskupa o przyjęcie go do seminarium włocławskiego na 4-letnie studia ${ }^{96}$.

Z korespondencji na ten temat widać wyraźnie, że chociaż pozwolenie na przyjęcie kandydata do klasztoru jasnogórskiego wydawał generał-gubernator warszawski, to jednak czynił to dopiero po porozumieniu się z Departamentem Spraw Duchownych Obcych Wyznań w Petersburgu. Tak np. było w wypadku kandydata Edmunda Grzesikowskiego ${ }^{97}$. Kolejnym kandydatem do klasztoru był Lucjan Jaksa, pochodzący z miejscowości Bytoń. 8 sierpnia 1881 r. przybył on do nowicjatu i nadano mu imię Filip ${ }^{98}$.

Biskup Popiel pozwolił klerykowi włocławskiego seminarium diecezjalnego, Wincentemu Brondzo, przenieść się do paulinów ${ }^{99}$. Po obłóczynach na Jasnej Górze kontynuował on nadal naukę we Włocławku ${ }^{100} .27$ grudnia 1882 r. ks. Marceli Sikorski, wikariusz z Łowicza, prosił biskupa, aby pozwolił mu wstąpić do klasztoru paulinów, i też otrzymał zgodę ${ }^{101}$. W 1883 r. pojawiło się dwóch kandydatów do klasztoru: 36-letni Teodor Kuczkowski i 28-letni Franciszek Nawrocki,

${ }^{90}$ ADWł, V 21 - Paulini, Przełożony do wizytatora 2/14 IX 1881.

${ }^{91}$ ADWł, V 21 - Paulini, Kubaczek do Wizytatora 11 VI 1879.

${ }^{92}$ ADW1, V 21 - Paulini, Wizytator do przeora 28 X 1872.

${ }^{93}$ ADWł, V 21 - Paulini, Biskup Popiel do wizytatora 26 XI 1880

${ }^{94}$ ADWł, V 21 - Paulini, Kubaczek do wizytatora 12 XI 1880.

${ }^{95}$ ADW1, V 21 - Paulini, Bp Popiel do wizytatora 30 XI 1880.

${ }^{96}$ ADW1, V 21 - Paulini, Wizytator do bpa kujawsko-kaliskiego 9 XII 1881.

${ }^{97}$ ADWł, V 21 - Paulini, Biskup Popiel do wizytatora 22 II 1881.

${ }^{98}$ ADWł, V 21 - Paulini, Kubaczek do Wizytatora 18 VIII 1881. Warto odnotować, że na liście biskupa do wizytatora, zawiadamiającym o tym, jako sekretarz podpisany jest ks. M. Lorentowicz, późniejszy wizytator klasztorów i proboszcz kościoła św. Barbary w Częstochowie Por. ADWł, V 21 - Paulini, Biskup Wincenty do wizytatora 10 X 1881.

${ }^{99}$ ADW, V 21 - Paulini, Bp Popiel - do wizytatora 19 IX 1881.

${ }^{100}$ ADW1, V 21 - Paulini, Kubaczek do wizytatora 10 X 1881.

${ }^{101}$ ADWł, V 21 - Paulini, Sikorski do biskupa 
o czym już nowy przeor, o. Piotr Kubarski, z radością zawiadomił wizytatora ks. Kozłowskiego ${ }^{102}$.

Po przeniesieniu przez Stolicę Apostolską bpa Popiela na metropolitę warszawskiego, nowym biskupem kujawsko-kaliskim został w 1882 r. dotychczasowy sufragan żmudzki, biskup Bereśniewicz. Wkrótce po odbyciu ingresu do katedry włocławskiej 1 lipca 1883 r., nowy biskup postanowił odwiedzić Częstochowę. Przybył na Jasną Górę 25 sierpnia/6 września 1883 r. i pozostał tam do 29 sierpnia/10 września. Nawiedził on wtedy wszystkie częstochowskie świątynie, na Jasnej Górze odprawił sumę odpustową w święto Narodzenia NMP oraz bierzmował wielu pielgrzymów ${ }^{103}$.

Doświadczony biskup od razu zauważył bolączki klasztoru, w tym brak wystarczającej liczby kapłanów. Zażądał on od przeora Kubarskiego danych tych kapłanów diecezjalnych, którzy kiedykolwiek wyrazili chęć wstąpienia do klasztoru oraz nazwisk kandydatów świeckich ${ }^{104}$. Przeor Kubarski przekazał mu nazwiska księży diecezjalnych, którzy wyrazili pragnienie wstąpienia do klasztoru, a ponadto nazwiska tych paulinów, którzy pozostawali na placówkach duszpasterskich w różnych diecezjach.

Starający się o przyjęcie do klasztoru kandydat Teodor Kuczkowski, który już otrzymał pozwolenie z ministerstwa na wstąpienie do konwentu, żalił się w lutym 1885 r. wobec biskupa, że przełożony Jasnej Góry nie chce go przyjąć ${ }^{105}$. Jednak w czerwcu 1885 r. przeor poinformował ks. wizytatora o przybyciu 16 stycznia 1885 r. Teodora Kuczkowskiego, kandydata na kleryka, a 19 maja kapłana diecezji płockiej ks. Edwarda Michniewskiego. Przeor prosił więc wizytatora, aby biskup wystarał się u generał-gubernatora o pozwolenie wciągnięcia przybyłego właśnie z zesłania o. Banawentury Gawełczyka i dwóch kandydatów na listę zakonników etatowych ${ }^{106}$.

Zdarzali się tacy kandydaci, którzy zdobywali wymagane przez prawo państwowe pozwolenie na wstąpienie do klasztoru jasnogórskiego, chociaż nie zdobyli akceptacji przełożonego. Wizytator i biskup czynili starania, aby ochronić klasztor przed takimi ,powołaniami”. Nieraz przed nieodpowiednim kandydatem przestrzegali biskupa sami urzędnicy państwowi. Natomiast kandydaci, których oceniano pozytywnie, budzili w klasztorze uzasadnioną nadzieję. Np. na początku 1886 r. przeor Kubarski poinformował wizytatora o pojawieniu się 4 dobrych kandydatów. Natomiast powrót do klasztoru o. Jodela raczej zasmucił przeora niż go ucieszy ${ }^{107}$. Biskup Bereśniewicz, pragnać ochronić klasztor od nieodpowiedniego postępowania o. Jodela, naznaczył go na wikariusza w parafii Lututów. O. Jodel wyjechał tam 13 kwietnia 1886 r. Tymczasem zbliżał się czas święceń kleryków: Brondzo i Jaksy. Zdając sobie sprawę z tego, że nie byli to idealni kandyda-

\footnotetext{
${ }^{102}$ ADWł, V 21 - Paulini, Kubarski do wizytatora 26 III 1883.

${ }^{103}$ Akta rzadu rosyjskiego, SC, 18 [podac ROK!!!!], s. 272.

${ }^{104}$ ADW1, V 21 - Paulini, Kozłowski do przełożonego 20 IX 1883.

${ }^{105}$ ADW', V 21 - Paulini, Wizytator do Kubarskiego 19 II 1885.

${ }^{106}$ ADWł, V 21 - Paulini, Kubarski do wizytatora 8 (?) VI 1885.

${ }^{107}$ ADW1, V 21 - Paulini, Kubarski do wizytatora 16 I 1886.
} 
ci na kapłanów, przeor nie nalegał na biskupa, czekając na opinię wychowawców seminarium ${ }^{108}$.

Bp Bereśniewicz w trosce o duchowe odrodzenie się jasnogórskiego klasztoru, doprowadził do odnowienia zaniedbanej klauzury. 20 czerwca 1892 r. wydał też zasady, które powinni przestrzegać nowicjusze. Podkreślał znaczenie magistra oraz obowiązki nowicjuszy, także będących już kapłanami. Nowicjusze-kapłani powinni byli codziennie 2 godziny słuchać spowiedzi ${ }^{109}$.

Mimo różnych wysiłków biskupa Bereśniewicza, liczba zakonników na Jasnej Górze już dawno spadła poniżej wyznaczonego przez władze państwowe limitu. Klasztor nie miał prawa prowadzić własne studia i nie posiadał kadry profesorskiej. Dlatego biskup ze zrozumieniem odniósł się do decyzji kapłana swojej diecezji absolwenta petersburskiej Akademii Duchownej i profesora Pisma św. w seminarium we Włocławku, ks. Józefa Przeździeckiego, który postanowił wstąpić do klasztoru jasnogórskiego. Biskup polecił mu jednak uprzednio zapoznać się z życiem zakonnym w klasztorze jezuitów w Karyntii. Po otrzymaniu pozwolenia władz państwowych ks. Przeździecki przybył na Jasną Górę, gdzie 4 lipca 1892 r. przyjął habit z rąk przeora o. Piotra Kubarskiego i otrzymał imię Pius. Jego wstąpienie do klasztoru zwiastowało nie tylko nadzieję, lecz i nowe wewnętrzne i wewnętrzne problemy. Niebawem został zesłany w głąb Rosji. 15 października 1895 r. ministerstwo spraw wewnętrznych wydało pozwolenie na przyjęcie kilku kandydatów: Antoniego Czurlanisa, Edmunda Papiewskiego, Henryka Cieplińskiego i Kacpra Macocha, o czym sam bp Bereśniewicz informował wizytatora ${ }^{110}$.

Biskup Bereśniewicz, podobnie jak i poprzednik, chętnie umożliwiał kandydatom paulińskim studiowanie w seminarium włocławskim. Osobiście zwracał się do odpowiednich władz, aby klerykom paulińskim udzielano pozwolenia na wyjazd do Włocławka. Przeor z Jasnej Góry starał się o to, by ich w ciągu roku odwiedzać ${ }^{111}$, a kierownictwo seminarium włocławskiego informowało konwent o postępach w życiu duchowym i naukowym kandydatów paulińskich, a także o mankamentach w tym zakresie ${ }^{112}$.

Większość kandydatów przyjmowanych do klasztoru jasnogórskiego długo w nim nie pozostawała. Dotyczy to zarówno kandydatów ze stanu świeckiego, jak i kapłanów. Nie czując się dobrze w klasztorze, sprawiali trudności przełożonym, zdradzając brak zakonnego powołania. Spośród wspomnianych wcześniej kandydatów, na Jasnej Górze nie pozostali prawdopodobnie: ks. Stanisław Koskowski z Królestwa Polskiego i ks. Jerzy Spasowski z mohylowskiej diecezji.

Ks. Nikodem Siedlecki z diecezji płockiej, po otrzymaniu w 1895 r. zgody od swojego biskupa i państwowego pozwolenia na wstapienie do klasztoru, przybył na Jasną Górę. Jednak wkrótce okazało się, że ks. Siedlecki nie czuje się dobrze w klasztorze. Już 30 czerwca 1898 r. urząd powiatowy poinformował przeora 0.

${ }^{108}$ ADWł, V 21 - Paulini, Kubarski do wizytatora 15 IV 1886.

${ }^{109}$ AJG 3195 - Aspiranci w ogólności, s. 219-223 - [Regulamin] bp Bereśniewicz 20 VI 1892.

${ }^{110}$ ADWł, V 21 - Paulini, Bp Bereśniewicz do Stopierzyńskiego (po 15 X 1895).

${ }^{111}$ AJG 2205, o. Euzebiusz Rejman, s. 241 - Uezdnoe upravlenie Rejmanu 31 XII 1897.

112 Por. J. Zbudniewek, Kontakty ks. Stanistawa Chodyńskiego z Jasną Górą, „Studia Włocławskie”, 10 (2007) s. 403-405. 
Rejmana o tym, że dla o. Kazimierza (takie imię zakonne przyjął) Siedleckiego przyszło pozwolenie wydania mu paszportu do Płocka. Okazało się jednak, że wyjechał on za granicę, dlatego w 1899 r. konsystorz włocławski zapytywał o datę jego wyjazdu. Bp Bereśniewicz zażądał, aby przeor wezwał przebywającego za granicą o. K. Siedleckiego do powrotu. O. Kazimierz powrócił do klasztoru 1 lutego 1900 r., o czym przeor Rejman w kilka dni później zawiadomił biskupa. O. Kazimierz narzekał na wilgoć w klasztorze, leczył się, a potem prawdopodobnie powrócił do diecezji ${ }^{113}$.

Nowym przeorem po śmierci o. Kubarskiego został stosunkowo młody o. Euzebiusz Rejman, absolwent seminarium włocławskiego. Wyrażał on radość z postawy nowicjuszy, którymi opiekował się również niedawno wyświęcony o. Alfons Jędrzejewski. O. Piusowi Przeździeckiemu, który powrócił z zesłania, powierzono wykłady dla nowicjuszy. Poprzez wizytatora przeor starał się o państwową pensję dla nich ${ }^{114} .7$ lipca 1897 r. o. Rejman zawiadomił wizytatora o skierowaniu do seminarium następujących nowicjuszy: Augustyna Jędrzejczyka, Ludwika Muszyńskiego, Bazylego Olesińskiego i Mikołaja Papiewskiego ${ }^{115}$. Paszporty do Włocławka musiał załatwić im biskup.

Wszyscy biskupi Królestwa Polskiego rozumieli trudną sytuację Jasnej Góry. Gdy udało im się zebrać wspólnie (bez informowania władz), uzgodnili sposób ratowania Jasnej Góry. Aby doraźnie wzmocnić liczebnie częstochowski konwent, biskupi postanowili zachęcić kapłanów poszczególnych diecezji do wstępowania do jasnogórskiego klasztoru ${ }^{116}$.

Biskup Stanisław Zdzitowiecki, który objął diecezję po zrzeczeniu się bpa Bereśniewicza, a właściwie po jego śmierci, postanowił upomnieć się u władz państwowych o umierające klasztory. W piśmie do ministra spraw wewnętrznych zwrócił on uwagę na surowe wymagania postawione przez państwo przed kandydatami do seminariów duchownych, w tym także zakonnymi. Biskup przypomniał, że według prawa państwowego zakonnicy mieli pomagać duchowieństwu diecezjalnemu w duszpasterstwie. Tymczasem wskutek likwidacji większości klasztorów liczba kapłanów zmalała, chociaż liczba ludności Kraju wzrosła 3krotnie. Biskup przypomniał władzom, że nieliczne istniejące jeszcze klasztory katolickie nie mają możliwości kształcenia własnych kandydatów na kapłanów $\mathrm{w}$ istniejących seminariach diecezjalnych, ponieważ nie mogą organizować u siebie kursów teologicznych, a od kandydata do seminarium żąda się ukończenia 4 klas gimnazjum. Prosił więc o pozwolenie, aby zakonnicy ${ }^{117}$ mogli nadal studiować

${ }^{113}$ AJG 2223, J. Góra. Personalia, 1892-1930, s. 77-191 - Siedlecki.

${ }^{114}$ ADWł, V 21 - Paulini, Rejman do wizytatora 29 I 1896, 2, II 1896, 3 II 1896

${ }^{115}$ ADWł, V 21 - Paulini, Rejman do wizytatora 7 VII 1897.

${ }^{116}$ Por. zwłaszcza materiały o. Piusa, zebrane w AJG w teczkach 1743, 2373, 2444, 2556, 2568 A i innych. Szereg krytycznych uwag o współbraciach pozostawił o. Alfons Jędrzejewski. Por. np. AJG 2739 A - o. Afons Jędrzejewski, [Pamiętnik].

${ }^{117}$ To znaczy kandydaci na kapłanów zakonnych. 
w seminarium włocławskim, lecz, aby od nich nie wymagano spełnienia takich samych warunków, jakie stawia się klerykom diecezjalnym ${ }^{118}$.

Inicjatywa ta wywołała obfitą korespondencję między klasztorem jasnogórskim, kurią włocławską i władzami państwowymi różnego stopnia, m. in. kancelarią generał-gubernatora warszawskiego. Władze żądały danych osobowych kandydatów zakonnych ${ }^{119}$. Generał-gubernator warszawski 1 grudnia 1911 r. przypomniał jednak, że należy stosować jednakowe kryteria dla wstępujących do seminarium duchownego.

Przed I wojną światową klasztor jasnogórski przeżył bardzo ciężkie chwile w związku z kradzieżą koron i sukienek z cudownego obrazu oraz z morderstwem w klasztorze, w którym uczestniczył jeden z zakonników. Wrogą postawę wobec przeżywającego tak ciężkie chwile klasztoru zaprezentowały nie tyle rosyjskie władze państwowe, które nigdy nie ułatwiały mu życia, lecz wszelka liberalna i socjalistyczna prasa. Nie był to czas dobry dla pojawienia się nowych powołań. Dopiero I wojna światowa i ponowne apele biskupów do kapłanów odmieniły tendencję spadkową.

\section{Rozwiązywanie problemów w klasztorze.}

W zaistniałej w drugiej połowie XIX w. sytuacji, w której znalazły się klasztory, tylko dobra współpraca między przełożonymi i biskupami oraz ich wizytatorami, mogła zapewnić klasztorowi przetrwanie. Jak wyżej stwierdziliśmy wizytatorzy okazali się ludźmi na wysokości zadania. Zachowując pozory lojalności wobec władz państwowych, byli wykonawcami woli biskupów i starali się o dobro duchowe klasztoru jasnogórskiego. Biskupi odwiedzali Jasną Górę corocznie, zwłaszcza z okazji święta Narodzenia NMP ${ }^{120}$, interesowali się życiem konwentu troszczyli się o to, aby klasztor miał dopływ powołań. Poniżej opisujemy troskę rządców diecezji kujawsko-kaliskiej wyrażającą się w rozwiązywaniu problemów wewnętrznych i zewnętrznych klasztoru.

Biskup Marszewski po kasacie klasztorów paulińskich musiał rozwiązać problem obsady duszpasterzami dotychczasowych parafii, obsługiwanych przez paulinów,w tym parafii św. Zygmunta w Częstochowie. Ostatni jej proboszczpaulin o. Wojciech Razumski ${ }^{121}$ przeżył nie tylko kasatę klasztoru paulinów przy tym kościele, lecz również upaństwowienie prawie całego mienia, należącego do parafii. Mienie to w rosyjskich dokumentach nazwano ,,poduchownym”. O. Razumskiemu kazano ponadto płacić czynsz za dom nr 148, w którym mieszkał,

${ }^{118}$ AJG 2195, Aspiranci, s. 179-180 - Zdzitowieckij - Ministru vnutrennyh del 21 VII/ 3 VIII 1911.

${ }^{119}$ AJG 2195, Aspiranci, s. 189 - Kancelariâ gen-gub. - Episkopu kuâvsko-kališskomu 3 X 1911.

120 Było ono wówczas na Jasnej Górze najbardziej uroczyście obchodzonym świętem maryjnym.

${ }^{121} \mathrm{~W}$ dokumentach tego czasu nie używano oddzielnego terminu na oznaczenie kapłana zakonnego. Zarówno w języku polskim, jak i rosyjskim pisano zawsze „ksiądz” (ks.). 
czyli prawdopodobnie domu parafialnego ${ }^{122}$. Państwo odebrało nie tylko majątek należący do parafii i klasztorów, lecz również do bractw kościelnych ${ }^{123}$.

Biskup Marszewski, jak stwierdziliśmy wcześniej, wielokrotnie zwracał się do władz państwowych, aby umożliwiły paulinom wyjazdy poza miasto celem zakupu tańszej żywności. Wikariusz kapitulny, ks. Skupieński wstawiał się za aresztowanym o. Gawełczykiem. Lecz najbardziej w obronę Jasnej Góry zaangażowani byli biskupi: Chościak-Popiel, Bereśniewicz i Zdzitowiecki. Poniżej przedstawiamy najważniejsze przejawy tej troski.

Władze utworzonej w 1867 r. guberni piotrkowskiej, a w szczególności gubernator Iwan Semionowicz Kachanow bardzo żywo interesowały się sytuacją na Jasnej Górze i ruchem pielgrzymkowym. Sprawozdania gubernatora trafiały poprzez general-gubernatora do ministerstwa spraw wewnętrznych w Petersburgu. Podawano w nich dokładną liczbę pielgrzymów przybywających na Jasną Górę i miejsca, skąd oni przybywali. Kachanow poinformował np. o przybyciu na Jasną Górę 25 sierpnia/6 września 1877 r. bpa Popiela. Biskup ten w okresie od sierpnia do października 1877 r. odbywał kanoniczną wizytację parafii w okolicach Częstochowy, gdzie był owacyjnie witany. 26 sierpnia (wg starego stylu) odprawił on w klasztorze jasnogórskim uroczyste nabożeństwo. Było to z okazji święta Narodzenia NMP, gromadzącego znaczną liczbę pielgrzymów ${ }^{124}$.

Gdy podobnie uroczyście witano bpa Popiela w Częstochowie w 1878 r., władze Królestwa Polskiego surowo upomniały go za to, zawiadamiając oczywiście o tym Departament Spraw Duchownych Obcych Wyznań w Petersburgu. Generał-gubernator warszawski Paweł Jewstafiewicz Kotzebue 8/20 października 1977 r. zganił biskupa Popiela za to, że pozwala na takie formy powitania, które jakoby należały się tylko osobom panującym ${ }^{125}$. Bp. Popiel udzielił wówczas na Jasnej Górze bierzmowania 13 tysiącom pielgrzymów ${ }^{126}$. Gdy władze ponowiły upomnienia, biskup, który już przeżył zesłanie w głąb Rosji, postanowił więcej nie ryzykować. W czasie jego obecności na Jasnej Górze w 1881 r. nie było już żadnych owacji, o czym władze guberni z zadowoleniem raportowały do Petersbur$\mathrm{ga}^{127}$.

Pełniący obowiązki zakrystiana na Jasnej Górze chory i przeciążony pracą o. Ficenes głośno wobec pielgrzymów wyrażał swoje zdenerwowanie. Przeor Kubaczek bronił jednak zakrystiana wobec wizytatora i biskupa. Tłumaczył, że nie ma on komu powierzyć tej funkcji, ponieważ starsi ojcowie już się nie nadają do tak trudnej pracy. Obawiał się, że gdyby powierzył ją młodszemu zakonnikowi, w zakrystii mogłoby zaczać się pijaństwo, gra w karty i podważanie jego władzy, jak to już bywało w przeszłości. Biskup Popiel, który osobiście był świadkiem nie-

${ }^{122}$ APCz, Mag. Cz., sygn.. 516, s. 96-97.

${ }^{123} \mathrm{APCz}$, Mag. Cz., sygn., 528, s. 90.

${ }^{124}$ RGIA, F. 821, op. 2, d. 305, 5-10 [Informacje Kachanowa]. Por. Akta rządu Carskiego, SC, 18 (1998) s. 249-251.

${ }^{125}$ Por. Akta rząu rosyjskiego, SC, 18 (1998) s. 252.

${ }^{126}$ Tamże, s. 253.

${ }^{127}$ ADWł, V 21 - Paulini, Rzewuski do Popiela 2/14 V 1877. Por. Akta rzq̨du carskiego, SC, 18 (1998) s. 251-268. 
grzecznego zachowania o. Ficenesa, uwzględnił racje o. Kubaczka i zgodził się na pozostawienie o. Ficenesa na stanowisku, lecz radził nie dopuszczać go do kontaktu z ludźmi ${ }^{128}$.

Gdy na Jasnej Górze zawakowało stanowisko wikariusza, przeor Kubaczek 27 grudnia 1878 r. zaproponował na nie o. Stanisława Kapiczyńskiego. Po zgłoszeniu tej kandydatury przez biskupa Popiela władzom Królestwa Polskiego, generał-gubernator nie zgodził się na nią, o czym sam biskup 2 lutego 1879 r. powiadomił wizytatora ${ }^{129}$. Przeor zaproponował więc kandydaturę o. Barnaby Ptakowskiego. Gdy generał-gubernator ja zaakceptował ${ }^{130}$, o. Barnaba 1 maja tego roku przyjął obowiązki ${ }^{131}$.

Biskup Popiel otrzymywał z Częstochowy sygnały o tym, że o. Kubaczek z powodu starości i choroby nie radzi sobie na stanowisku przeora Jasnej Góry. Postanowił więc uzyskać odpowiednie pozwolenie rządowe na naznaczenie na to stanowisko innego paulina, o. Piotra Kubarskiego. Gdy załatwienie tej sprawy było już w toku, a o. Kubaczek złożył już rezygnację, okazało się, że w sprawę odwołania o. Kubaczka zaangażowany był naczelnik powiatu częstochowskiego. Zachęcał on paulinów, aby przełożonego zmienili, a potem zaczął o. Kubaczka bronić, przedstawiając go od najlepszej strony. O grze naczelnika powiatu poinformował biskupa Popiela wikariusz klasztoru, o. Bonawentura Ptakowski, przestrzegając go jednak przed ewentualnym pozostawieniem o. Kubaczka jako człowieka mściwego na stanowisku przeora ${ }^{132}$.

Ponieważ w roku 1882 wypadała 500-rocznica obecności cudownego obrazu na Jasnej Górze, paulini w uzgodnieniu z wizytatorem klasztorów, odpowiednio wcześnie postanowili zwrócić się do biskupa Popiela, aby wyjednał u Stolicy Apostolskiej łaski jubileuszowe dla pielgrzymów, zaprosił na tę uroczystość innych biskupów, aby uprosił prawo nadawania nadzwyczajnych odpustów dla wszystkich spowiedników, którzy będą spełniali posługę w czasie uroczystości, ponadto, by wyjednał u władz prawo sprawowania obrzędów i głoszenia kazań na zewnątrz klasztoru ${ }^{133}$. Popiel zaakceptował też propozycje zakonników ${ }^{134}$, aby w sanktuarium zostały przeprowadzone renowacje kaplicy Matki Bożej oraz aby informacja o uroczystościach jubileuszowych została ogłoszona w prasie ${ }^{135}$. Prace w kaplicy miały niebawem się rozpoczynać. Ojcowie zaręczyli się zgodą Komitetu ds. kontroli funduszy jasnogórskich.

O. przeor Piotr Kubarski odpowiadając na zapytanie biskupa, objaśnił, że sanktuarium jasnogórskie posiada następujące przywileje: potwierdzony przez Benedykta XIV przywilej kapituły Bazyliki Santa Maria Maggiore w Rzymie z 14

${ }^{128}$ ADWł, V 21 - Paulini. Korespondencja ta trwała w latach 1878-1880.

${ }^{129}$ ADWł, V 21 - Paulini, Biskup Wincenty do wizytatora 4 lutego 1879 r.

${ }^{130}$ ADWł, V 21 - Paulini, Popiel do Wizytatora 25 IV 1879 oraz Wizytator do przeora 29 IV 1879.

${ }^{131}$ ADW , V 21 - Paulini, Kubaczek do wizytatora 2 V 1879.

${ }^{132}$ ADW1, V 21 - Paulini, Ptakowski do wizytatora i bpa Popiela 29 X 1881.

${ }^{133}$ ADWł, V 21 - Paulini, Wizytator do Popiela 15 XII 1881.

${ }^{134}$ ADWł, V 21 - Paulini, Kubarski do wizytatora 11 III 1882.

${ }^{135}$ ADW', V 21 - Paulini, Popiel do wizytatora 18 III 1882. 
lutego 1751 r., mówiący o tym, że pątnicy odwiedzający jasnogórską świątynię dostępują tych samych odpustów, co i nawiedzający rzymską bazylikę, sanktuarium ma prawo do 4 penitencjarzy apostolskich i do korzystania $\mathrm{z}$ wielu różnych odpustów. Zaznaczył jednak, że udzielenie nowych łask bullą papieża Leona XIII mogłoby podnieść splendor uroczystości ${ }^{136}$.

Informacje o przygotowaniach do 500-letniej rocznicy obecności obrazu MB Częstochowskiej docierały różnymi drogami do władz państwowych. Doniesienia gubernatora piotrkowskiego Kachanowa i generał-gubernatora warszawskiego Albiedinskiego o planowanych w Częstochowie uroczystościach i o planach biskupa Popiela, by z tej okazji zwrócić się do papieża Leona XIII o nadanie pielgrzymom nadzwyczajnych przywilejów (odpustów), docierały do rosyjskiego ministerstwa spraw wewnętrznych. Władze pozwoliły biskupowi Popielowi, by oficjalną drogą zwrócił się z odpowiednią prośbą do papieża. Apel taki biskup Popiel skierował do papieża w marcu 1882 r. Pod naciskiem władz musiał jednak zapewnić, że uroczystości będą obchodzone skromnie, wewnątrz klasztoru i będą miały charakter miejscowy i wyłącznie religijny, bez akcentów ogólnopolskich i historycznych. Po upływie miesiąca w Rzymie zostało wystawione odpowiednie bre$\mathrm{we}^{137}$.

Władze państwowe zażądały ponadto, aby wszystkie kazania na tę uroczystość zostały poddane cenzurze. Przeor miał więc nie lada problem. Żaden bowiem ze znanych kaznodziejów, którzy zgodzili ${ }^{138}$ się głosić wtedy Słowo Boże, nie zechciał dawać swoich tekstów do cenzury, dlatego przeor był zmuszony przekazać władzom odpowiednią ilość przykładowych kazań.

Rząd, swoim zwyczajem, odkładał przekazanie biskupowi Popielowi przygotowanego w Rzymie dokumentu. Sprawę uroczystości jubileuszowych konsultował nie tylko z biskupem katolickim, lecz także z Cerkwią prawosławną. Generałgubernator postawił twarde warunki. Oprócz biskupa Popiela na jubileusz mógł przybyć tylko jeden biskup - Kuliński z Kielc. Aby nie dopuścić do przybycia na Jasną Górę byłych unitów, zabroniono w ogóle przyjazdu do Częstochowy pielgrzymom z guberni suwalskiej, łomżyńskiej, siedleckiej i lubelskiej. Do Częstochowy wydelegowani zostali tajni agenci policji i odpowiedni oddział wojska. Agenci codziennie informowali swoich przełożonych o przebiegu uroczystości jubileuszowych. Doniesienia te były sukcesywnie wysyłane do Petersburga. Informowano o ilości pielgrzymów oraz z dużym zadowoleniem podawano, że w kazaniach nie było treści politycznych ${ }^{139}$.

${ }^{136}$ ADWł, V 21 - Paulini, Kubarski do wizytatora 16 III 1882.

${ }^{137}$ Korespondencja między gubernatorem piotrkowskim Kachanowem, warszawskim generałgubernatorem Albiedinskim, ministrem spraw wewnętrznych Ignatiewem, oberprokuratorem Pobienoscowem, imperatorem na temat uroczystości jasnogórskich w 1882 r. Por. Akta rzq̨du carskiego, SC, 18 (1998) s. 254-272.

${ }^{138}$ ADWł, V 21 - Paulini, Kubarski do wizytatora 24 III 1882.

${ }^{139}$ Korespondencja między gubernatorem piotrkowskim Kachanowem, warszawskim generałgubernatorem Albiedinskim, ministrem spraw wewnętrznych Ignatiewem, oberprokuratorem Pobienoscowem i imperatorem na temat uroczystości jasnogórskich w 1882 r. Por. Akta rządu carskiego, s. 254-272. 
W 1884 r. Jasną Górę nawiedził generał gubernator warszawski i, ponownie jak przed rokiem, chełmsko-warszawski arcybiskup prawosławny Leontij. Na Jasnej Górze urządzono im uroczyste przyjęcie. Biskup Bereśniewicz, wyrażając swoją dezaprobatę, rozesłał całemu duchowieństwu diecezji okólnik, w którym wyjaśnił, że taki sposób przyjęcia należy się jedynie panującemu, a nie biskupowi niekatolickiego wyznania ${ }^{140}$. Biskup wezwał 7 listopada 1884 r. przeora o. Kubarskiego do Włocławka, gdzie według doniesień, które otrzymywał gubernator, miał poddać go pokucie ${ }^{141}$.

Ksiądz katecheta, pracujący w szkole żeńskiej w Częstochowie Władysław Górzyński napiętnował uczennice-katoliczki, które brały udział w pogrzebie luteranki, żony prawosławnego nauczyciela tej szkoły. Powiedział, że Kościół nie pozwala swoim wyznawcom brać udziału w liturgii i obrzędach innych wyznań. Władze oceniły wystąpienie katechety jako przejaw braku tolerancji religijnej. Podejrzewały, że jest ono związane z treścią okólnika biskupa Bereśniewicza. Okólnik ten był wydany 15 listopada $1884 \mathrm{rr}^{142}$. Stało się to przyczyną poważnych problemów biskupa, który został wezwany do Petersburga, i groziło mu zesłanie.

Mimo troski bpa Popiela, a następnie Bereśniewicza, znajdujący się niedaleko Jasnej Góry klasztor paulinów z kościołem św. Barbary, po usunięciu z niego nowicjatu i skasowaniu przez władze państwowe znajdującego się tam osobnego konwentu paulinów klasztoru, podupadał. Car przekazał znajdującemu się w Kosprzy kościelnym klasztor w użytkowanie Powiatowej Radzie Towarzystw Dobroczynnych, jednak ona nie kwapiła się z zagospodarowaniem budynku do i gotowa była go odsprzedać. Ponieważ duszpasterstwo w tym kościele całkowicie zamierało, bp Bereśniewicz zamierzał naznaczyć na duszpasterza u św. Barbary aktywnego o. Bonawenturę Gawełczyka, który 7 marca 1885 r. powrócił z zesłania i bardzo gorliwie włączył się w duszpasterstwo na Jasnej Górze. Jasnogórski konwent był jednak już tak osłabiony, że nie mógł oddać do św. Barbary tak gorliwego kapłana. Przeor Kubarski uprosił więc biskupa, aby o. Bonawenturę pozostawił na Jasnej Górze, a do św. Barbary skierował jednego ze starszych ojców ${ }^{143}$.

$\mathrm{W}$ czasie duszpasterzowania w kościele św. Barbary schorowanego o. Kubaczka, władze państwowe przeprowadziły w jego mieszkaniu nocną rewizję i zarekwirowały mu znaczną sumę pieniędzy (12 tys. rubli srebrem). Ks. Kubaczek objaśnił, że znaczna część tej sumy należy osobiście do niego i do jego sługi, natomiast reszta była jakoby intencjami mszalnymi, jednak dokładnie o. Kubaczek nie potrafił wyjaśnić. Biskup Bereśniewicz zdołał odzyskać zarekwirowane pieniądze. Władze, uwzględniając thumaczenie o. Kubaczka, pozwoliły na to, by część pieniędzy została zwrócona zakonnikowi i jego słudze, drugą część biskup

\footnotetext{
${ }^{140}$ Bp Bereśniewicz użył tego samego argumentu, jakiego używały kiedyś władze, upominając bpa Popiela.

${ }^{141}$ RGIA, F. 821, op. 125, d. 3064 - Delo o rassledovanii narušenij rasporiaženij pravitelstva upr. Kujawsko-kališepiskopom A. K. Beresnevičem i dr. licami, č, 1.8 - Donesenije gubernatora do ministra vnutrennyh del 10 XII 1884.

${ }^{142}$ Data jest późniejsza niż doniesienie gubernatora, co prawdopodobnie oznacza, że dokument był datowany wg. nowego stylu, por. Tamże, 1.8 odwr. nn.

${ }^{143}$ Płatek, Dzieje paulinów, s. 151-155.
} 
rozdał różnym kapłanom do odprawienia jako intencje mszalne a pozostałą -przeznaczył na remonty w klasztorze jasnogórskim ${ }^{144}$.

Ponieważ Częstochowa rozbudowywała się jako miasto przemysłowe, a jedyna parafia częstochowska przy kościele św. Zygmunta rozpościerała się daleko poza jej granice, biskup Aleksander Bereśniewicz poparł propozycje utworzenia przy kościele św. Barbary nowej parafii. Dzięki tej jego decyzji uratowany został kościół św. Barbary i niebawem odzyskany został klasztor przy nim, skasowany przez cara już w roku 1872. Należy to mocno podkreślić, ponieważ i dzisiaj oskarża się bpa Bereśniewicza, że on zabrał paulinom klasztor z kościołem św. Barbary ${ }^{145}$.

Duchowni paulini, pozostający przy kościele św. Barbary, nie otrzymali odpowiedniego uposażenia, a nawet próbowano ich pozbawić możliwości uprawiania $\operatorname{ogrodu}^{146}$. Próby odwołania się do państwowej praworządności dały jedynie chwilowy rezultat ${ }^{147}$. Klasztor nie spełniał już wymogów klasztoru nieetatowego, gdyż nie było w nim nawet 8 zakonników. W efekcie został on niebawem skasowany, chociaż przynajmniej jeden kapłan pozostawał tam praktycznie aż do utworzenia parafii.

Utworzenie nowej parafii było palącą potrzebą duszpasterską w obliczu wielokrotnego zwiększenia się liczby mieszkańców Częstochowy. Była to ludność robotnicza. Pozostawiona bez opieki duszpasterskiej, mogła łatwo być utracona

${ }^{144}$ Sprawę tę szczegółowo opisał w swojej kronice o. Dąbrowski. Por. AJG 2366, cz. III - Kronika, napisana przez o. Czesława Dąbrowskiego za rządów o. Euzebiusza Rejmana, 18641909.

${ }^{145}$ Taką tezę opublikował po opuszczeniu Jasnej Góry i przybyciu do Krakowa o. Ambroży Fedorowicz. Teza ta została powtórzona w artykule: J. Zbudniewek, Jasna Góra w okresie niewoli narodowej, s. 78. Jednakże napisane na Jasnej Górze Kroniki zakonne, zebrane w AJG, całkowicie ją obalają. Por. AJG 2440 A, P. Markiewicz zp., Kronika zakonu 1864-1940. (Odpis wierny z rękopisu 2440) [r. 1945], s. 6-12. Por. też: AJG 2366, J. Góra. Sprawa Pius Przeździecki - Przeor Rejman, 1864-1909, cz. III - Kronika, napisana przez o. Czesława Dąbrowskiego za rządów o. Euzebiusza Rejmana, 1864-1909.

${ }^{146}$ Klasztor przy kościele św. Barbary nie został w 1864 r. skasowany, lecz pozostawiony jako swoista filia Jasnej Góry. Zlikwidowano jedynie nowicjat. Klasztor pozostał jako pozaetatowy, mieszkający tam zakonnicy pozostawali bez utrzymania. Przeor Jasnej Góry, o. Aleksander Zięba 31 stycznia 1870 r. żalił się naczelnikowi powiatu na to, że przy kościele św. Barbary mieszka dwóch kapłanów, nie mających żadnego utrzymania. Ponadto władze żądały, aby za działkę-ogród o powierzchni 6 morgów 106 prętów płacić podatek 44 rubli 68 kopiejek. Podobnie też apelował przeor Kubaczek. Por. APCz, Mag. Cz. 544, s. 123-125.

${ }^{147} \mathrm{~W}$ odpowiedzi na te starania Piotrkowska Izba Skarbowa ogłosiła 14 III 1870, że dyrektor zarządzający sprawami duchownymi wyznań obcych w Królestwie Polskim 19/31 I 1870 napisał do urzędu gubernialnego, że zgodnie z artykułem 26 Dodatkowych zasad do ukazu z 27 X/8 XI 1864 o rzymsko-katolickich klasztorach w Królestwie Polskim od przejęcia na skarb państwa są wyjęte sady i ogrody, konieczne do funkcjonowania klasztoru. Magistrat częstochowski opracował więc raport, w którym podano racje przemawiające za koniecznością pozostawienia klasztorowi jasnogórskiemu i przy kościele św. Barbary. Prezydent Częstochowy i inżynier powiatowy wnioskowali więc, aby ogród przy kościele św. Barbary był pozostawiony w użytkowanie duchowieństwu klasztoru. Por. APCz, Mag. Cz., 544, s. 180-190. 
dla Kościoła i to w bezpośrednim sąsiedztwie Jasnej Góry. Do kościoła św. Barbary uczęszczało bowiem coraz mniej wiernych, a skierowany tam chory i konfliktowy o. Teodor Mochalski, nie zdołał wywiązać się z oczekiwanych zadań.

Bp Bereśniewicz skierował do kościoła św. Barbary początkowo jako wikariusza młodego kapłana diecezjalnego, ks. Bolesława Wróblewskiego. Rada Opiekuńcza Towarzystw Dobroczynnych powiatu częstochowskiego, w użytkowanie której przekazany został niegdyś klasztor, nie zagospodarowała go i gotowa była go odsprzedać powstającej parafii. Biskup Bereśniewicz uzyskał odpowiednie carskie pozwolenie na to, aby przy kościele ustanowiono parafię i aby mogła ona odkupić budynki klasztoru ${ }^{148}$. Parafia przy kościele św. Barbary została więc erygowana 3 sierpnia $1991 \mathrm{r}$. a jej pierwszym proboszczem został mianowany ks. Michał Lorentowicz, kanonik kapituły katedralnej i regens konsystorza generalnego włocławskiego, późniejszy diecezjalny wizytator klasztorów ${ }^{149}$.

24 października 1891 r. zmarł były przeor Jasnej Góry o. Laurenty Kubaczek, o czym przeor Kubarski zawiadomił wizytatora ${ }^{150}$. Niektórzy zakonnicy nadużywali dobroci biskupa, który każdorazowo starał się o pozwolenie generał-gubernatora na wyjazdy zakonników z klasztoru. Biskup o załatwieniu sprawy informował przez wizytatora. Np. o. Mokrski często korzystał z takiego pośrednictwa ${ }^{151}$.

Biskup Bereśniewicz starał się nadal pomagać klasztorowi przezwyciężyć wewnętrzny kryzys, dlatego zgodnie z propozycją wizytatora klasztorów, zaproponował na stanowisko przeora dotychczasowego prokuratora, energicznego o. Euzebiusza Rejmana ${ }^{152}$. Władza biskupa nad klasztorem okazywała się dla niego ratunkiem zwłaszcza wtedy, gdy przełożeni nie mogli sobie poradzić z nieposłusznym zakonnikiem. Ponieważ niemałe kłopoty sprawiał niedawno wyświęcony na kapłana o. Filip Jaksa, biskup Bereśniewicz zmuszony był zabrać go z klasztoru. Naznaczył go na wikariusza parafii Piotrków Kujawski ${ }^{153}$.

Przyjęty do zakonu o. Pius Przeździecki był kapłanem bardzo gorliwym i odpowiedzialnym oraz wielkim polskim patriota, przy tym był typem zeloty, niezbyt skłonnym do kompromisu. Niebawem popadł on w konflikt $\mathrm{z}$ nowym przeorem Jasnej Góry, o. Euzebiuszem Rejmanem, człowiekiem bardzo praktycznym i ambitnym. Ponieważ o. Rejman podejmował na Jasnej Górze wiele różnych dzieł

${ }^{148}$ Por. Sytuację tę wyjaśnia o. Zachariasz Jabłoński w artykule: Jasna Góra w drugiej połowie XIX wieku i na poczatku XX wieku - jej udział w dązeniach niepodległościowych, w: Częstochowa. Dzieje miasta i klasztoru jasnogórskiego, t. 2 - Wokresie niewoli 1793-1918, red. R. Kołodziejczyk, Częstochowa 2005, s. 171-173. Pokrótce sytuację kościoła św. Barbary wyjaśnia także ks. Jan Związek, Kościól częstochowski na przełomie wieków, w: Częstochowa. Dzieje miasta i klasztoru jasnogórskiego, t. 2 - W okresie niewoli 1793-1918, red. R. Kołodziejczyk, Częstochowa 2005, s. 139-142.

${ }^{149}$ Por. AJG 2366, cz. III - Kronika, napisana przez o. Czesława Dąbrowskiego za rządów o. Euzebiusza Rejmana, 1864-1909, s. 33-41.

${ }^{150}$ ADW1, V 21 - Paulini, Kubarski do Stopierzyńskiego 24 X 1891.

${ }^{151}$ ADW1, V 21 - Paulini, Bp Bereśniewicz do Stopierzyńskiego 3/15 XI 1895.

152 J. Grajek, Z Częstochowy, Nowy przeor i nowy zakonnik, „Gazeta Świąteczna”, r. 15, 748 (1895), s. 6.

${ }^{153}$ ADWł, V 21 - Paulini, Biskup Bereśniewicz do wizytatora ks. Stopierzyńskiego 9 VI 1890. 
materialnych, mimowolnie zaniedbał troskę o duchowy stan klasztoru. O. Pius Przeździecki był przekonany o konieczności odrodzenia Jasnej Góry. Ponieważ był bardzo aktywny, władze rosyjskie niejednokrotnie usuwały go z klasztoru. Przeor Rejman nie za bardzo go bronił, gdyż według jego oceny o. Pius postępował nierozsądnie. W ten konflikt biskup musiał być siłą rzeczy wciągnięty. Zwłaszcza o. Pius wysyłał mu dokładne skargi i objaśnienia.

Biskup Bereśniewicz w trosce o świętość Jasnej Góry wydał w r. 1885 okólnik, którym wzywał kapłanów, aby pouczali lud, jak ma się zachować w czasie pielgrzymki. Polecał, aby chorągwie, z którymi przybywają pielgrzymi, były składane w jednym miejscu i aby lud zachowywał się spokojnie. Biskup wzywał kaznodziejów do tego, aby uprzedzali wiernych, aby ci nie poddawali się prowokacjom. Obawiał się np. aktów podkładania dynamitu, napadów na Żydów i w efekcie do obniżenia poziomu religijnego wśród ludu ${ }^{154}$.

Biskup wydał też odpowiednie zarządzenia w związku z epidemią cholery, która zapanowała w kraju i uniemożliwiała odbywanie pielgrzymek. Polecał, aby kapłani zanosili odpowiednie modlitwy. Podobnie też wzywał do publicznego dziękczynienia po ustaniu zarazy ${ }^{155}$.

Ponieważ nieliczni już paulini eksploatowali wszystkie swoje siły w służbie pielgrzymom, nie byli w stanie zajmować się pracą społeczną w rozwijającym się mieście. Biskup Bereśniewicz planował utworzenie oprócz parafii św. Barbary, nowych parafii w Częstochowie. W parafii św. Zygmunta zaczęto przygotowywać się do budowy nowego dużego kościoła ${ }^{156}$. Biskup nie mógł przyjeżdżać do Częstochowy często, dlatego przybywając na jasnogórskie uroczystości, bierzmował tam tysiące wiernych. Widząc potrzebę aktywnego duszpasterstwa w mieście, posyłał do parafii częstochowskich gorliwych kapłanów ${ }^{157}$.

Z jego życzliwości wobec Jasnej Góry korzystał nowy przeor, o. E. Rejman, który często zwracał się do biskupa Bereśniewicza o jego pośrednictwo w sprawie otrzymania paszportu na wyjazd. O życzliwości bpa Bereśniewicza do niego świadczy fakt, że on bardzo często sam zawiadomił go o otrzymaniu od generałgubernatora pozytywnej decyzji ${ }^{158}$. Biskup Bereśniewicz chętnie załatwiał aktyw-

${ }^{154}$ AJG 1114 - Jasna Góra 1721-1898. Kaznodzieja niedzielny, s. 35-38; Por. ADWł, V 21 - Paulini, Bereśniewicz 13 X 1885 [Okólnik].

${ }^{155}$ AJG 1073 - Opieka nad pątnikami 1706-1921, s. 15 - Dziekan Nowakowski komunikuje zarządzenia Pasterza z 16 III 1893 i z 29 V 1893.

${ }^{156}$ Inicjatorem tej budowy był wikariusz, ks. Sylwester Barancewicz. Początkowo planowano budować kościół na miejscu starego cmentarza, lecz w końcu zdecydowano się na nowy plac w pewnej odległości od kościoła św. Zygmunta. Ze względu na opory biurokracji rosyjskiej, starania trwały wiele lat. Proboszcz Mikołaj Nowakowski nie doczekał się rozpoczęcia budowy kościoła św. Rodziny. Zmarł 24 stycznia 1901 r., a budowę rozpoczął już nowy proboszcz, ks. Józef Waberski. Podobnie też bp Bereśniewicz ze względu na podeszły wiek nie był już w stanie przybyć do Częstochowy na uroczystość poświęcenia kamienia węgielnego pod jego budowę. Uczynił to bp sufragan Henryk Kossowski 7 listopada 1902 r. Nową, jeszcze nie wykończoną świątynię, poświęcił 7 grudnia 1907 r. przeor Jasnej Góry o. Euzebiusz Rejman. Por. Związek, Kościół częstochowski, s. 142.

${ }^{157}$ Por. Związek, Kościót częstochowski, s. 142-143.

${ }^{158}$ AJG 2205, o. Euzebiusz Rejman, s. 203 - Episkop Rejmanu 17/29 I 1997. 
nemu przeorowi Rejmanowi pozwolenia na ciągłe wyjazdy i zbiórki ofiar na klasztor w całej diecezji kujawsko-kaliskiej ${ }^{159}$. O. Rejman zdając sobie sprawę z tego, że poprzez ciągłe prośby o pośrednictwo w załatwieniu pozwoleń na opuszczenie Jasnej Góry, sprawia biskupowi kłopot, poprosił go o pomoc w załatwieniu stałego paszportu. Jednakże generał-gubernator nie wydał takiej zgody. Zaznaczył, że przeor powinien starać się oddzielnie o pozwolenie na każdy następny wyjazd w sprawach osobistych ${ }^{160}$. O. Rejman, doceniając troskę dostojnego ordynariusza o Jasną Górę, udał się osobiście do Włocławka na jego jubileusz w roku $1897^{161}$.

Bp Bereśniewicz pragnął, aby zostały zbadane i opracowane pewne dokumenty $\mathrm{z}$ archiwum jasnogórskiego. Takie zadanie otrzymał wspomniany już wcześniej kapłan diecezji kujawsko-kaliskiej, ks. Władysław Górzyński. Nie wiemy, czy inicjatywa badania dokumentów paulińskich pochodziła od niego samego, czy też bp Bereśniewicz chciał zainteresować zdolnego młodego kapłana pracą naukową. Biskup polecił kierownictwu klasztoru dopuścić go do kwerendy, zaznaczając jednak wyraźnie, że ma to czynić w określonym czasie i nie wolno mu wynosić z klasztoru żadnego dokumentu. Nie zostało to jednak zachowane. Dokumenty wydano księdzu Górzyńskiemu do domu. Ten, prawdopodobnie będąc bardzo zajęty innymi obowiązkami, długo ich nie zwracał. Nie wiemy też, czy udało mu się na ich podstawie napisać jakieś opracowanie ${ }^{162}$.

Specyfiką duszpasterstwa polskiego, odziedziczonego po poprzednich pokoleniach, była duża ilość bractw kościelnych, działających przy kościołach parafialnych i zakonnych. Władze państwowe wymogły na biskupie, aby poprzez dziekanów zebrał on informacje o istniejących przy kościołach parafialnych i zakonnych bractwach oraz o ich statutach, gdyż w przeciwnym wypadku będą one zlikwidowane. Biskup Bereśniewicz zobowiązał więc dziekanów, aby statuty bractw zostały napisane po polsku i po rosyjsku. Uczynił to prawdopodobnie na wyraźne żądanie władz państwowych ${ }^{163}$.

O. Rejman bywał też na uroczystościach kościelnych poza Jasną Góra. Głosił np. kazanie na pogrzebie dziekana ks. Mikołaja Nowakowskiego w 1901 r. ${ }^{164}$.

${ }^{159}$ O pobytach o. Rejmana w Warszawie, „Kraj” 31 (1897), s. 2. Por. też: AJG 2206, o. Euzebiusz Rejman. Zawiadomienia o zezwoleniu na wydanie paszportu o. Rejmanowi zostały wysłane 22 czerwca 1899 r., (s. 7), 3 listopada 1899 r., (s.17 i 19), 21 września 1900 r. (s. 61), w styczniu 1901 r., o tym pozwoleniu zawiadomił częstochowski policmajster (s. 75), 30 marca 1901 r. (s. 87), 30 czerwca 1901 r. (s. 89), 14 lipca 1901 r. (s. 93), 29 listopada 1901 r. (s. 109), 16 stycznia 1902 r. (s. 125). 11 sierpnia 1903 r. o wydaniu paszportu Rejmanowi zawiadomił go policmajster (s. 169). 14 X 1903 urząd powiatowy wydał o. Rejmanowi odręczny bilet (zabrakło blankietów paszportów) (s. 175), o czym 18 lutego 1904 r. zawiadomił go naczelnik powiatu (s. 211). Por. AJG 2206.

${ }^{160}$ AJG 2205, o. Euzebiusz Rejman, s. 233 - Bereśniewicz Rejmanu 3/15 VI 1897.

${ }^{161}$ XX, Jubileusz J. E. Ks. Biskupa Bereśniewicza, „Rola”, r. 15 (1897 ) s. 636.

${ }^{162}$ Por. Zbudniewek, Kontakty ks. Stanisława Chodyńskiego z Jasną Górą, „Studia Włocławskie” 10 (2007) s. 405-408.

${ }^{163}$ AJG 696 - Bractwa, s. 13-14 - dziekan Nowakowski do przeora 1 V 1888.

${ }^{164}$ Ks. W. P., Częstochowa, „Wiek”, 33 (1901) s. 6. 
Za biskupa Bereśniewicza, widocznie z inspiracją abpa Popiela z Warszawy, podjęto decyzję o budowie Drogi Krzyżowej wokół murów Jasnej Góry. 15 października 1897 r. Adam Koziarski z Warszawy zwrócił się do generał-gubernatora o pozwolenie na to, aby warszawscy pielgrzymi mogli zbierać ofiary na wybudowanie na Jasnej Górze stacji Drogi Krzyżowej ${ }^{165}$. Warszawski oberpolicmajster zażądał jednak, aby projekt każdej stacji zatwierdził gubernator piotrkowski. Sprawa pozwolenia na zbieranie ofiar na zbudowanie 14 stacji Drogi Krzyżowej miała być rozstrzygnięta przez naczelnika powiatu częstochowskiego. Ten nie okazał sprzeciwu wobec zbierania pieniędzy na ten cel. Za pozwoleniem władz zostały też wydrukowane z datą17 luty 1898 r. odpowiednie książeczki do zapisywania ofiar na urządzenie Drogi Krzyżowej ${ }^{166}$.

Rysunki stacji przeor klasztoru 29 stycznia/10 lutego 1899 r. przekazał naczelnikowi powiatu, celem przesłania do gubernatora ${ }^{167}$. Gubernator chciał $\mathrm{m}$. in. wiedzieć, jaka będzie wielkość brązowych figur Męki Pańskiej ${ }^{168}$. Przeor Rejman oświadczył, że figury będą wielkości człowieka, lecz do każdej rzeźby należy też krzyż ${ }^{169}$. Projekt każdej ze stacji został zaaprobowany przez biskupa Bereśniewicza, a 28 maja tego roku - przez gubernatora piotrkowskiego. Budowa była kontynuowana przez szereg lat ${ }^{170}$.

Na początku XX w. o. Rejman zaczął starać się w Rzymie o otrzymanie prawa noszenia insygniów biskupich, podobnego do tego, które mają opaci w starych klasztorach. Sprawa ta została w Rzymie załatwiona, odpowiedni dekret został podpisany 24 maja 1901 r., lecz wysłane drogą oficjalną dokumenty, władze rosyjskie zatrzymały. Car Mikołaj II wydał zgodę na przekazanie o. Rejmanowi dokumentów informujących o udzieleniu takiego przywileju dopiero 17 listopada 1904 r. Dokumenty te 10 XII 1904 r. zostały przesłane nowemu biskupowi kujawsko-kaliskiemu, Stanisławowi Zdzitowieckiemu.

Biskup Zdzitowiecki po ingresie na stolicę we Włocławku 23 listopada 1902 r., podobnie jak i jego poprzednik, często bywał na Jasnej Górze, zwłaszcza na uroczystości odpustowe. Podczas pierwszego pobytu w Częstochowie biskup ogłosił się opiekunem i obrońcą Jasnej Góry. 15 sierpnia 1906 uczestniczył w uroczystości poświęcenia odbudowanej po pożarze wieży klasztornej.

Nowy ordynariusz w czasie pobytu w Rzymie podjął sprawę nadania kościołowi jasnogórskiemu tytułu bazyliki. 25 grudnia 1906/7 stycznia 1907 r. poinformował o tym cara Mikołaja II oraz premiera i ministra spraw wewnętrznych w jednej osobie P. A. Stołypina. Zdając sobie sprawę z tego, że mógł zostać oskar-

${ }^{165}$ AJG 2131 - Stacje 1884-1930, s. 7 - Kancelaria petrokovskogo gubernatora Načalniku Čenstohovskogo uezda 10 II 1898. W rzeczywistości inicjatorem zbierania funduszy na wybudowanie Drogi Krzyżowej w fosach był przeor Rejman. To on zainspirował Koziarskiego. Por. Rejman, Memoriat, SC, 13 (1993) s. 252.

${ }^{166}$ AJG 2131 - Stacje, s. 9 - Kancelaria varšavskogo ober-policmejstra - General-gubernatoru 14 II 1898.

${ }^{167}$ AJG 2131 - Stacje, s. 69 - Nastoâtel' - v uezdnoe upravlenie 29 I/ 10 II 1899.

${ }^{168}$ AJG 2131 - Stacje, s. 121 - Gubernator Načelniku 8/20 II 1899.

${ }^{169}$ AJG 2131 - Stacje, s. 123 - Nastoâtel' Uezdnomu Načalniku 17 II 1899.

${ }^{170}$ AJG 2131 - Stacje - Zdjęcia projektów (bez paginacji). 
żony o pominięcie pośrednictwa rządu Rosji w kontaktach ze Stolicą Apostolską, thumaczył, że tytuł ten nie jest związany z otrzymaniem żadnych przywilejów, lecz jest wyrazem jedynie większej godności. Ministerstwo przez Departament spraw duchownych wyznań obcych postanowiło sprawdzić pochodzenie nazwy „bazylika” oraz, jakim kościołom przysługuje ten tytuł. Toczyła się korespondencja pomiędzy ministerstwem, generał-gubernatorem i biskupem, zanim zdecydowano, że dokument papieski wynoszący kościół jasnogórski do godności bazyliki może być przekazany biskupowi ${ }^{171}$.

Ponieważ bp Zdzitowiecki, podobnie jak i jego poprzednik, obdarzył dużym zaufaniem przeora Euzebiusza Rejmana ${ }^{172}$, zbyt bolesnym ciosem okazała się dla niego kradzież dokonana w kaplicy Matki Bożej 22 października 1909 r. i późniejsze bratobójstwo w klasztorze. Nosił się nawet z zamiarem odebrania klasztoru paulinom i przekazania go odradzającemu się zakonowi marianów ${ }^{173}$. Chodziło mu o uratowanie Jasnej Góry, aby pozostała ona nadal sanktuarium katolickim. Podobnie i inni biskupi Królestwa Polskiego i spoza niego pragnęli pomóc odrodzić się duchowo klasztorowi ${ }^{174}$.

Przeor Rejman przejął się, nie mającą jednak podstaw w źródłach myślą, że nowe korony dla cudownego obrazu na miejsce skradzionych może podarować sam imperator Mikołaj II, symbolicznie biorąc w ten sposób obraz wraz z klasztorem pod opiekę państwa, co mogłoby doprowadzić do przekazania klasztoru Kościołowi prawosławnemu ${ }^{175}$. Rejman wymyślił, że najlepiej by było, gdyby Ojciec św. podarował korony i dyskretnie podsunął tę myśl osobistościom w Rzymie, co wychwyciły gazety. DDDII z gazety „Neu Lodzer Zeitung” z 20 października 1909 r. dowiedział się o otrzymaniu przez o. Rejmana od papieskiego szambelana Sapiehy zapewnienia, że Ojciec św. Pius X życzy sobie podarować nowe korony dla okradzionego obrazu. O. Rejman odpowiedział telegramem, że jest gotów przyjąć dar papieża. Wobec tego dyrektor Departamentu 1/13 listopada 1909 r. oskarżył więc Rejmana, że popełnił on przestępstwo przeciwko paragrafowi 17 Ustawy Wyznań Obcych, zabraniającemu kontaktować się z Kurią Rzymską bez pośrednictwa ministerstwa spraw wewnętrznych ${ }^{176}$. Na thumaczenia o. Rejmana ministerstwo spraw wewnętrznych przypomniało mu, że we wszystkich

${ }^{171}$ Akta rządu carskiego, „SC” 18 (1998), s. 300-302. Dokumenty pochodzą z RGIA F. 821, op. 2, d. 306 - Perepiska s varšavskim gen-gubernatorom o predostavlenii raznyh privilegii nastoâm Čenstohovskogo Jasnogorskogo monastyrâ Petrokovskoj gub., o vosstanovlenii nastoâtelâmi bez razrešeniâ monašeskogo kapitula, uprazdnennogo v 1864 g., i ustanovlenii svâzej s Rimom 19011910, 1. 26-33.

${ }^{172}$ Por. AJG 2366, J. Góra. Sprawa o. Pius Przeździecki - przeor Rejman. 1864-1909, s. 4988.

${ }^{173}$ Chodziło mu o zademonstrowanie wobec władz carskich, że panuje nad sytuacją, aby nie dać pretekstu do zamknięcia klasztoru.

${ }^{174}$ Sprawy te obiektywnie wyjaśnia w swojej „Kronice” o. Piotr Markiewicz. Por. AJG 2440 A,

P. Markiewicz zp., Kronika zakonu 1864-1940. (Odpis wierny z rękopisu 2440) [r. 1945], s. 33-35.

${ }^{175}$ Rejman, Memoriat, s. 263.

${ }^{176}$ AJG 2117 - Koronacja cud. Obrazu, 1910, s. 3-5 - Rejman do DDDII 9 XI 1909 (brudnopis). Treść tej odpowiedzi z datą 10 XI 1909 podana jest w: SC, 18 (1998) s. 311 jako dokument 190. 
sprawach: oficjalnych i prywatnych można kontaktować się z Rzymem jedynie oficjalną drogą poprzez rząd rosyjski $i^{177}$. Ponieważ jednak sprawa ta została szeroko nagłośniona, władze dyplomatycznie pozwoliły o. Euzebiuszowi na wyjazd do Rzymu i przywiezienie koron bez opłaty celnej ${ }^{178}$.

Bp Zdzitowiecki w piśmie do ministerstwa spraw wewnętrznych zaproponował członków oficjalnej delegacji dla przywiezienia koron. W jej skład oprócz o. Rejmana mieli wchodzić prałat Karol Max i inne osoby. Polscy biskupi postanowili aktywnie włączyć się do aktu koronacji. Pozwolenie na wyjazd do Częstochowy, oprócz biskupów z Królestwa Polskiego, otrzymał m. in. bp Jan Cieplak z Petersburga ${ }^{179}$.

Koronacja Matki Bożej złotymi koronami ofiarowanymi przez papieża Piusa X odbyła się na Jasnej Górze 22 maja 1910 r., w uroczystość Trójcy Przenajświętszej. Do Częstochowy przybyło pięciu biskupów. Bp Zdzitowiecki wygłosił kazanie, a następnie w imieniu Ojca Świętego nałożył korony na obraz.

Wielka aktywność zewnętrzna o. Rejmana, jego zaangażowanie w prace budowlane, przy tym częsta jego nieobecność w klasztorze, przyczyniły się do obniżenia poziomu duchowego w klasztorze. Według późniejszej oceny o. Piotra Markiewicza inteligentny, troskliwy i zapobiegliwy o. Rejman, pod koniec swojej służby na stanowisku przeora, zatracił zdolność trzeźwej oceny sytuacji ${ }^{180}$.

Biskup Zdzitowiecki zdawał sobie sprawę z tego, że jeśliby o. Rejman pozostał na stanowisku przeora, nie będzie łatwo rozwiązać problemów klasztoru. Został wybrany już nowy przeor o. Weloński, lecz władze państwowe nie uznały tego wyboru. Biskup poprosił więc o. Euzebiusza, aby złożył formalną, czyli na piśmie w języku rosyjskim, rezygnację ${ }^{181}$. I taka rezygnacja z datą 6 VII 1910 r. do biskupa dotarła ${ }^{182}$.

Jednakże pełniący obowiązki warszawskiego generał-gubernatora Anton Ottowicz von Essen ${ }^{183}$ nie zgodził się na wybór o. Justyna na przeora ${ }^{184}$. Przeszkodą miał być jakoby jego zaawansowany wiek. Także dyrektor DDDII A. Charuzin przypomniał biskupowi, że zasady wyborów przełożonych klasztorów katolickich jasno zostały określone w art. 207 Ustawy Wyznań Obcych. Według tego artykułu kapituła klasztoru nie posiadała prawa wyboru przeora. Podobnie też przypomnia-

${ }^{177}$ AJG 2117 - Koronacja cud. Obrazu..., 1910, s. 9-10 Kryžanovskij - Rejmanu 20 XI 1909.

${ }^{178}$ AJG 2207 - Person. o. Rejmana III, s. 7 - Menkin Rejmanu 28 III 1910.

179 Akta rzadu carskiego, SC, 18 (1998) s. 307-336. Dokumenty pochodzą z RGIA, F. 821, op. 2, d. 307 - Perepiska s kuj.-kal. ep. i nastoâtelem ...o pohiŝenii dragocennostej s ikony B. M. i o požertvovanii papoj korony dlâ nazvannoj ikony, 1907-1910.

${ }^{180}$ AJG, o. Piotr Markiewicz, Kronika Zakonu Paulinów, s. 23.

${ }^{181}$ AJG 2159, Wybory przeorów, s. 49 - Kuâvsko-kališskij episkop - nastoâtelu Rejmanu VII 1910.

${ }^{182}$ AJG 2159, Wybory przeorów, s. 35 - [Rejman] - E[go] Preosv[âŝenstvu] Kuâvskokališskomu E[piskopu] - 6 VII 1910.

${ }^{183}$ Von Essen Anton Ottowicz w latach 1905-1910 był gubernatorem piotrkowskim. Potem, będąc zastępcą generał-gubernatora warszawskiego, dwukrotnie przez krótki czas pełnił obowiązki Naczelnika kraju.

${ }^{184}$ AJG 2159, Wybory przeorów, s. 57 - Essen - Zdzitovieckomu 13 VII 1910. 
no, że stanowisko kustosza, które powierzono o. Piusowi Przeździeckiemu, zostało zlikwidowane ${ }^{185}$. Kiedy biskup Zdzitowiecki zapewnił, że o. Justyn Weloński jest w pełni sił, nowy generał-gubernator warszawski Skałon ${ }^{186}$, po uzgodnieniu sprawy z ministerstwem spraw wewnętrznych, zatwierdził o. Welońskiego na stanowisku przeora ${ }^{187}$. Biskupi z Królestwa Polskiego i spoza niego pragnęli pomóc częstochowskiemu klasztorowi odrodzić się duchowo. Jednak władze państwowe nie zezwalały na zebrania biskupów w celu omówienia ważnych, bieżących problemów ${ }^{188}$.

Wkrótce po koronacji cudownego obrazu Matki Bożej na Jasnej Górze w dniu 24 czerwca 1910 r. dokonano tam morderstwa, które odbiło się szerokim echem w kraju i poza granicami. Spowodowało ono duże zamieszanie w społeczeństwie polskim. Biskup został wezwany przez władze do zdecydowanych działań. Minister Spraw Wewnętrznych Rosji proponował i nalegat, aby biskup Zdzitowiecki „Z całą mocą swego autorytetu zajął się przywróceniem porządku w klasztorze”. Jego zdecydowane kroki okazały się bolesne dla częstochowskiego konwentu. W stosunku do klasztoru jasnogórskiego polska opinia społeczna pogorszyła się. Istniała nawet groźba rozwiązania zakonu paulinów.

Gdy jednak biskup wziął klasztor pod osobisty zarząd i wyznaczając do jego kontroli swych komisarzy, władze państwowe zaniepokoiły się ${ }^{189}$. Rząd rosyjski z premierem Piotrem Stołypinem na czele zdał sobie sprawę z tego, że dotychczasowy system prowadzenia sprawozdawczości o kapitałach klasztoru jasnogórskiego według przepisów z 20 kwietnia 1874 r. nie zdaje egzaminu. Dlatego władze zaprosiły bpa Zdzitowieckiego do wypracowania nowych przepisów w tym zakresie. Biskup zrozumiał, że gdyby się zgodził na współpracę, przyczyniłby się do jeszcze większego ubezwłasnowolnienia klasztoru. Ograniczył się więc do kilku uwag, np. zwrócił uwagę czynnikom rządowym na to, że w okresie zimowym ustaje ruch pielgrzymkowy, więc i ofiar brakuje. Podkreślił też, że w okresie dużego napływu pielgrzymów wszyscy zakonnicy są tak zapracowani, że nie jest rzeczą możliwą zapisywanie wszelkich ofiar. Zaproponował zmniejszenie ilości ksiąg do czterech. Gubernator piotrkowski Jaczewski zrozumiał, że biskup gra na zwłokę i poradził, aby władza nie traciła czasu na bezsensowną korespondencję z nim, lecz wypracowała własny projekt prowadzenia kontroli. Do komitetu kontrolującego sumy klasztorne poradził, oprócz trzech wybieranych osób, włączyć

\footnotetext{
${ }^{185}$ AJG 2159, Wybory przeorów, s. 69 - Haruzin - Zdzitovieckomu 27 VIII 1910.

${ }^{186}$ Skałon Georgij Antonowicz (1847-1914) - generał gubernator warszawski w latach 19051914.

${ }^{187}$ Biskupi byli zobowiązani do kontroli klasztorów przez swoich wizytatorów. Por. AJG 2159, Wybory przeorów, s. 73 - Skalon - Zdzitovieckomu 4 X 1910.

${ }^{188}$ Por. AJG 2440 A, P. Markiewicz zp., Kronika zakonu 1864-1940. (Odpis wierny z rękopisu 2440) [r. 1945], s. 33-35.

${ }^{189}$ Jego interwencja na Jasnej Górze była emocjonalna i prawdopodobnie niesprawiedliwa wobec zakonników, którzy pozostawali wiernymi Kościołowi, lecz chodziło mu przede wszystkim o zademonstrowanie wobec władz carskich, że panuje nad sytuacją, aby nie dać pretekstu do zamknięcia klasztoru.
} 
także policmajstra powiatu częstochowskiego i radcę urzędu gubernatorskiego $^{190}$.

Ochrona klasztoru jasnogórskiego nie była dla bpa Zdzitowieckiego sprawą łatwą i w następnych latach. Władze państwowe były bowiem dobrze zorientowane w sytuacji na Jasnej Górze, ponieważ miały tam swoich informatorów. Chociaż wiedziały o istniejących w klasztorze stronnictwach, to jednak przeprowadzały nowe kontrole. Takie śledztwo zostało powierzone przez p.o. warszawskiego generał-gubernatora pracownikowi jego urzędu, Wasylowi Tiażelnikowowi. To on prawdopodobnie skłonił policmajstra powiatu częstochowskiego, kapitana Czesnakowa, do przeprowadzenia rewizji w mieszkaniu o. Piusa Przeździeckiego ${ }^{191}$. Tiażelnikow niebawem awansował na stanowisko w DDDII. Wykazał się wtedy wielką pomysłowością w rozpracowywaniu Kościoła katolickiego w Rosji ${ }^{192}$.

W jasnogórskim klasztorze, pomimo zmiany przeora, nadal nie było jedności wśród zakonników. Ponieważ do opozycji wobec przeora Welońskiego zostali wciągnięci klerycy, zachodziła obawa, że po ich święceniach i ślubach, powróci sytuacja sprzed lat. Dlatego biskup Zdzitowiecki poparł ideę ich usunięcia, na co władze w końcu się zgodziły ${ }^{193}$. Jeden z młodszych ojców, Alfons Jędrzejewski ośmielał się krytykować nawet samego biskupa S. Zdzitowieckiego. Aby nie dopuścić do tego, że po śmierci o. Welońskiego o. Alfons zostanie przeorem, biskup „awansował go" na gwardiana klasztoru bernardynów w Kole, któremu groziło zamknięcie ${ }^{194}$.

Wielką próbą dla Jasnej Góry i biskupa Zdzitowieckiego był proces sądowy w Piotrkowie w sprawie zbrodni na Jasnej Górze. Delegowany na proces przez DDDII 8 lutego 1912 r. Tiażelnikow, jawnie występował przeciw paulinom ${ }^{195}$. Władze państwowe nie były jednak zainteresowane w duchowym odrodzeniu klasztoru. Pragnąc mieć klasztor pod kontrolą, od lat utrzymywały instytucję kolegium ds. kontroli sum pieniędzy, przynoszonych na Jasną Górę. Członkowie kolegium po złożeniu w magistracie przysięgi na wierną służbę, po wezwaniu przez władze przychodzili prowadzić kontrolę razem z policmajstrem i innym państwowym urzędnikiem. W ten sposób naruszane było prawo biskupa do osobistej lub przez wizytatora kontroli nad klasztorem ${ }^{196}$.

Biskupa Zdzitowieckiego niepokojono z powodu wysłania przez klasztor jasnogórski jako stypendia mszalne do klasztoru paulinów w Krakowie sumy 6.962 rubli. Przypomniano mu, że pieniądze za granicę można wysyłać jedynie za zgodą

\footnotetext{
${ }^{190}$ Akta rzadu carskiego, s. 362-365.

${ }^{191}$ AJG 2249 [Tajne pisma], s. 43-45 - Raport Czesnakowa do gubernatora piotrkowskiego 10 III 1912.

${ }^{192}$ Por. np. szereg informacji o pracy Tiażelnikowa w pracy: B. Czaplicki, Katolicka działalność dobroczynna w Rosji w latach 1867-1918, Warszawa 2008.

${ }^{193}$ Por. materiały opublikowane w SC 18, s. $351 \mathrm{nn}$.

${ }^{194}$ Por. AJG 2739 A - o. Alfons Jędrzejewski [Pamiętnik].

${ }^{195}$ RGIA, F. 821, op. 128, d. 174, k. 1-7 - Komandirovka Tâželnikova 8 II 1912.

196 Biskupi i administratorzy diecezji kujawsko-kaliskiej w ramach swoich możliwości troszczyli się o klasztor jasnogórski, chociaż warunki po temu, stworzone przez prawo państwowe były bardzo trudne.
} 
cesarza. Rządzący nie potrafili zrozumieć, że Msze św. w przyjętych intencjach należy obowiązkowo odprawić, a nie jest to możliwe na Jasnej Górze ze względu na małą ilość zakonników i utrudnienia ze strony władz, aby w jasnogórskim klasztorze pomagali kapłani diecezjalni ${ }^{197}$.

Podsumowując ten rozdział można stwierdzić, że poddanie klasztorów władzy biskupów okazało się dla Jasnej Góry zbawienne. Klasztor popadł w tak trudną sytuację, że o własnych siłach nie był w stanie się odrodzić.

\section{Zakończenie}

Władze rosyjskie powierzyły odpowiedzialność za katolickie klasztory biskupom. Aby nie dopuścić do całkowitej samowoli władz w tym zakresie, Stolica Apostolska potwierdziła to prawo, co wcale nie ułatwiało im życia. Jeszcze gorzej było wtedy, gdy diecezja przez długie lata pozostawała bez biskupa, a jej zarządcą bywał wybrany przez kapitułę kapłan, zwany administratorem. Biskup lub administrator diecezji sprawował jurysdykcję nad klasztorami osobiście lub poprzez wizytatora klasztorów. Naznaczenia na funkcje kościelne: biskupa, administratora, wizytatora, przeora i inne, zatwierdzane były przez władze rosyjskie. Każdy kapłan przed objęciem jakiegokolwiek stanowiska musiał składać przysięgę na wierność imperatorowi.

W omawianym przez nas okresie sytuacja Kościoła katolickiego w Królestwie Polskim była bardzo trudna. Życie zakonne zostało skazane na śmierć. Rządcy diecezji kujawsko-kaliskiej czynili wszystko, co było w ich mocy, celem uratowania klasztoru jasnogórskiego, aby mógł on spełnić swoją religijną i jednoczącą naród rolę. Wpierali ich wizytatorzy klasztorów.

W świetle przebadanych dokumentów nie ma podstaw do oskarżania biskupów lub wizytatorów o wrogość wobec klasztoru jasnogórskiego. Nie ma też żadnych dowodów na to, że któryś z rządców osobiście lub poprzez wizytatora wyrządził Jasnej Górze jakąś krzywdę. Wprost przeciwnie - stała troska biskupów o to sanktuarium oraz ich decyzje ratowały klasztor od niechybnego upadku.

Biskupi uzyskali zgodę władz państwowych na otwarcie nowicjatu i kształcenie kandydatów na kapłanów paulińskich we Włocławku. Chociaż prawo państwowe nie dawało takich możliwości, rządcy diecezji troszczyli się o przeprowadzenie w klasztorze reform w dziedzinie duchowej i administracyjnej. W sytuacji, kiedy władze państwowe metodą inwigilacji doprowadziły do powstania podziałów na Jasnej Górze, koniecznością było kierowanie do klasztoru kapłanów diecezjalnych oraz ingerowanie w obsadę stanowisk przełożonych. Chociaż diecezja kujawsko-kaliska była bardzo rozległa, biskupi bywali na Jasnej Górze o wiele częściej, niż w parafiach. Osobiście głosili Słowo Boże, celebrowali, bierzmowali tysiące wiernych. Gdy dostrzegali w klasztorze problemy natury wewnętrznej, interweniowali osobiście lub przez wizytatora, chociaż nie zawsze mogło to podobać się władzom państwowym. Przejęcie przez diecezję kościoła św. Zygmunta, a później św. Barbary, przyczyniło się do ich uratowania, a pośrednio ratowało

${ }^{197}$ Akta rzadu carskiego, s. 367-371. 
Jasną Górę. Klasztor ten przeżył bowiem pod koniec XIX w. tak głęboki kryzys, że niemożliwą by było dla niego rzeczą administrowanie rozległą i ciągle wzrastającą parafią, nie mówiąc już o podejmowaniu nowych inicjatyw duszpasterskich.

\section{Aneksy}

\section{1}

[Pismo]

(kopia, język rosyjski-tlumaczenie: ks. B. Czaplicki).

AJG 2195, Aspiranci w ogólności Jasnej Góry 1794-1924, s. 179-191

Biskup kujawsko-kaliski do Jego Wysokości Pana Ministra Spraw Wewnętrznych

21 lipca/ 3 sierpnia $1911 \mathrm{r}$.

Zgodnie z odpowiedzią Ministerstwa Spraw Wewnętrznych z 16 kwietnia 1909 r. nr 1780 P. Generał-gubernatorowi Warszawskiemu, wstapienie zakonników do rz.-k. seminarium może być dopuszczalne nie inaczej, jak tylko z zachowaniem wszystkich warunków przyjęcia do rz.-k. seminarium, i to jedynie w wypadku przedstawienia przez nich odpowiednich świadectw o ukończeniu przez nich wcześniejszego wykształcenia, wymaganego przez aktualne prawodawstwo od wszystkich osób w ogóle, pragnących wstąpić do rz.-k. seminarium. Postanowienie to stawia mnie w sytuacji trudnej. Zgodnie z kanonami i praktyką Kościoła rzymskokatolickiego, zakonnicy, z wyjątkiem nielicznych, którzy z powodu braku zdolności umysłowych lub cnoty pokory, pozostają przez całe życie braćmi, wszyscy powołani są do trudzenia się w stanie duchownym nad rozwojem Królestwa Bożego na ziemi, tzn. spowiadać i głosić Słowo Boże, i to głównie w naszym kraju, w sytuacji bardzo ograniczonej liczby klasztorów i osób zakonnych. Nie mogę także nie zauważyć tego, że podczas likwidacji w 1864 r. klasztorów było NAJWYSZĄ MONARSZĄ Wolą, aby pozostawione klasztory etatowe niosły pomoc duchowieństwu diecezjalnemu. Obecnie ludność Kraju zwiększyła się niemal 3-krotnie, a tymczasem liczne, w tym także etatowe klasztory zostały zlikwidowanie. Przy tym, zgodnie z wspomnianym postanowieniem Ministerstwa, są oni pozbawieni tej możliwości, chociaż na ich przyjęcie wydał zgodę Rząd. Studiowanie nauk teologicznych na miejscu [zakonnikom] prawnie zabroniono, zaś wstąpienie do Seminarium w celu otrzymania wykształcenia teologicznego zakazuje im wyżej zacytowane postanowienie. 
W rzadkich przypadkach wstępują do seminarium kandydaci po maturze. Najczęściej natomiast zakończenie kilku klas gimnazjum, a nawet wykształcenie domowe osób zdolnych, daje gwarancję uzupełnienia wszystkich braków wykształcenia. Przy tym oni (tj. zakonnicy - B. Cz.), nie kierując parafią, nie mając za wyjątkiem przełożonego bezpośrednich kontaktów z Władzami Administracyjnymi, nie są zmuszeni przez sytuację do posiadania takiej znajomości języka rosyjskiego, jakiej wymaga od kapłanów diecezjalnych.

Chociaż do tej pory w stosunku do osób zakonnych nie były zachowywane ogólne wymagania, odnoszące się do wstępujących do seminariów, jednak kapłani zakonni, jak o tym mogli przekonać się delegowani do klasztoru jasnogórskiego: urzędnik do spraw szczególnych w Ministerstwie, P. Pietrow i kierownik wydziału w Departamencie Spraw Wewnętrznych, P. Tiażelnikow, którzy obcowali z nimi blisko i rozmawiali, zauważyli u nich wystarczającą znajomość języka rosyjskiego. W wypadku opuszczenia klasztoru przez kapłanów zakonnych, zgodnie z istniejącą praktyką, są oni poddawani dodatkowemu egzaminowi, zgodnie $z$ postanowieniem $P$. Warszawskiego Generał-gubernatora.

Wszyscy kandydaci, zgłaszający się do klasztoru, zgodnie z prawem kanonicznym, powinni pod czujną obserwacją kierownictwa klasztoru, przeżyć przynajmniej rok próby, czy są oni zdolni do życia zakonnego, wymagającego nadzwyczajnej stałości charakteru i wyrzeczenia światowej marności i uciech. W tym wypadku, nawet ci, którzy ukończyli 4 lub nawet 6 klas nauk, zgodnie z istniejącym prawodawstwem, powinni powtórnie zdawać egzamin z rosyjskich przedmiotów, a tym samym uczyć się i przygotowywać się za pomocą innych osób, co jest zabronione przez prawo, i co mogłoby wywołać podejrzenie miejscowych Władz Administracyjnych, jakoby w klasztorze zorganizowano kursy naukowe. Z powodu powyżej przedstawionych przyczyn, mam zaszczyt pokornie poprosić Waszą Wysokość o pozwolenie wszystkim kandydatom do klasztoru pobierać naukę przedmiotów teologicznych w podlegającym mnie Włocławskim seminarium duchownym, bez zachowania ogólnych przepisów, jakie są wymagane od wstępujących do seminarium, jak to było praktykowane przed wydaniem zasad z 16 kwietnia $1909 \mathrm{r}$.

Biskup Kujawsko-kaliski [St. Zdzitowiecki] Regens konsystorza [ks. Ad. Owczarek]

2

List p.o. warszawskiego generat-gubernatora do biskupa S. Zdzitowieckiego

(kopia, język rosyjski-ttumaczenie: ks. B. Czaplicki)

AJG 855 [Zakaz pomocy duszpasterskiej. 1911-1912], s. 19 
Varšavskij gen. Gubernator

16 II 1911

nr 656

Do kujawsko-kaliskiego biskupa rzymskokatolickiego

Minister spraw wewnętrznych w piśmie z 19 stycznia nr 931 przesłał mnie kopię swojej odpowiedzi nr 930 pod adresem Waszej Ekscelencji, dotyczącej naruszeń prawa $\mathrm{i}$ innych nieporządków, jakie miały miejsce $\mathrm{w}$ częstochowskim klasztorze paulinów. Przy tej okazji Sekretarz stanu Stołypin zauważył, że szczególnie ważnym jest:

1.Zdecydować, aby kontrola klasztoru ze strony wizytatora miała miejsce w rzeczywistości, i aby nie sprowadzała się do prostej formalności, 2. Zażądać od wizytatora wypełniania paragrafu 204 Ustawy Wyznań Obcych, dotyczącego każdorocznego składania Wam ogólnego sprawozdania z tym, aby ono po Waszym sprawdzeniu i z Waszymi uwagami o sytuacji klasztoru, było przekazane mnie w celu przekazania do Ministra spraw wewnętrznych, 3 . Bezzwłocznie zlikwidować samowolnie utworzoną kapitułę i wynikającą stąd zasadę wybieralności przeora. 4. Zamknąć powstałe wbrew prawu kursy teologiczne, 5. Szczególną ostrożność należy wykazywać podczas przyjmowania osób, pragnących włączyć się do liczby zakonników, 6 . Usunąć z klasztoru osoby nie mające prawa w nim zamieszkiwać, a także nie dopuszczać takich w przyszłości, 7. zestawić i przedstawić do zatwierdzenia przez Ministerstwo zaproponowany przez par. 226 Ustawy Obcych Wyznań etat służby klasztornej, 8. Zaproponować kierownictwu klasztoru, aby zatroszczyło się o wypełnienie par. 228 Ustawy Wyznań Obcych, dotyczącego legitymacyjnych biletów i 9 . Na nowo przejrzeć zasady z 20 kwietnia 1874 roku o rozliczeniu pieniężnym i projekt nowych zasad dostarczyć do Ministerstwa celem zatwierdzenia.

Informując o niniejszym, proszę Waszą Ekscelencję, niezależne od podjęcia bardzo stanowczych kroków w kierunku natychmiastowego zrealizowania wymienionych w odpowiedzi Ministra Spraw Wewnętrznych nr 930 pod Waszym adresem i w punktach 3, 4 i 6 niniejszej mojej odpowiedzi wymagań prawa, śledzić za bezwzględnym wypełnieniem przepisów, wymienionych powyżej w punktach: 1, 2, 5 i 8, a także w uzgodnieniu z gubernatorem piotrkowskim, zestawić etat dla służby klasztornej (p. 7), przejrzeć zasady z 20 kwietnia 1874 r., oraz stwierdzić, jakie etaty i projekty nowych przepisów, powinny być mnie przedstawione poprzez Kamergera Jaczewskiego, w celu przesłania ich przeze mnie do Ministerstwa. kach.

Proszę Was zawczasu informować mnie o podejmowanych przez Was kro-

P. o. generał-gubernatora, jego zastępca: Essen 
List Biskupa S. Zdzitowieckiego do ministra spraw wewnętrznych A. A. Makarowa

(kopia, język rosyjski-tlumaczenie: ks. B. Czaplicki).

AJG 855 [Zakaz pomocy duszpasterskiej. 1911-1912], s. 14-15.

(s. 14) Ego Vy-stvu G. Ministru Vnutrennyh Del D. T. S. (rzeczywisty tajny radca) A. A. Makarovu - K.K. (kujawsko-kaliski) Episkop S. Zdzitoveckij, 14/27 X 1911, nr 3301

Negatywna odpowiedź nr 8915 z 4 września br. na moją prośbę w sprawie pozwolenia kapłanom diecezjalnym przez bardzo krótki czas zamieszkiwać W ścianach klasztoru jasnogórskiego dla zaspokojenia religijnych potrzeb ludności, stawia mnie w sytuacji bez wyjścia, dlatego też zdobywam się na śmiałość ponownie zwrócić się do Waszej Wysokości z pokorną prośbą, aby raczył Pan zwrócić swoją życzliwą uwagę na moje ponowne błaganie, a nawet w drodze wyjątku apelować do laski NAJWYŻSZEGO. Literalne zastosowanie prawa w tym wypadku pociągnie za sobą fizyczną niemożliwość zaspokojenia religijnych potrzeb niezliczonego mnóstwa przybywających na Jasną Górę wiernych, szukających tu pojednania z Bogiem, zaspokojenia duchownego głodu i nabrania sił w różnego rodzaju biedach tego doczesnego życia.

W roku bieżącym, zgodnie z informacją miejscowej jednostki policyjnej, Jasną Górę odwiedziło ponad 400 tys. pielgrzymów. Niezaspokojenie potrzeb tak licznego ludu doprowadzi do niezadowolenia i szemrania. Ani na chwilę nie mogę przypuścić, (s. 15) aby zamiarem Rządu było spowodowanie swoimi działaniami ograniczającymi swobodę zaspokojenia potrzeb duchowych, zwłaszcza po ogłoszeniu z wysokości Tronu tolerancji, narzekań wierzącej części mieszkańców i tym samym doprowadzenie do obniżenia poziomu duchowego i osłabienia religijnego ładu, który jest najmocniejszą zaporą przeciwko destrukcyjnym antyspołecznym teoriom i dążeniom, co potwierdza doświadczenie wszystkich wieków.

Jestem mocno przekonany, że MONARCHA PANSTWA, który łaskawie raczył podarować swobodę sumienia, i którego jedyną troską jest duchowy i materialny rozwój wszystkich krajów tak obszernego Państwa, po zaprezentowaniu przez Waszą Wysokość, nie odmówi NAJWYŻSZEGO miłosierdzia w tak ważnej sprawie, bez innego wyjścia, tym bardziej, że prawo to zostało ustanowione ponad 40 lat temu, kiedy klasztor jasnogórski liczył ponad 50 kapłanów zakonnych, liczba ludności była prawie trzykrotnie mniejsza, a życie religijne, płynące wówczas własnym rytmem, nie było narażone na tak ciężkie i niebezpieczne doświadczenia. Oprócz tego nie mogę pominąć milczeniem i tego momentu, że nie ma takiego prawa, choćby najbardziej przemyślanego, wypośrodkowanego przez ludzi posiadających polityczny rozum, które byłoby zdolne objąć wszelkie przejawy życia, i nie dopuszczałoby możliwości wyłączenia pojedynczych wypadków.

Długie prawnicze i administracyjne doświadczenie Waszej Wysokości daje mi całkowitą podstawę żywić niesłabnącą nadzieję, że na moje błaganie, które wypływa z krzyczących religijnych potrzeb kraju, będzie zwrócona odpowiednia uwaga, i że Wasza Wysokość swoim poważnym autorytetem i wysokim patrona- 
tem nie przepuści, chociażby drogą miłosierdzia NAJWYZSZEGO, prosić o pozwolenie dla kapłanów diecezjalnych na przebywanie przez jakiś czas w murach klasztoru jasnogórskiego.

Przy tej okazji proszę Waszą Wysokość o przyjęcie zawierzenia o najgłębszym moim szacunku i szczerym oddaniu.

\author{
K. K. (kujawsko-kaliski) biskup: St. Zdzitowiecki
}

\title{
THE CONCERN OF THE BISHOPS OF KUJAWY-KALISZ FOR JASNA GÓRA AFTER THE JANUARY UPRISING (1864-1914)
}

\begin{abstract}
Summary
The author presents the issue of the relationships of the bishops from the Diocese of KujawyKalisz to Jasna Góra in the period after the January Uprising. Negative opinions spread about these bishops were the inspiration for this research. This study was based on a critical use of sources, which are in the Russian State Historical Archive in St. Petersburg, the Archive of Jasna Góra, the Diocesan Archive in Włocławek and the State Archive in Częstochowa. The author attempted to present the situation of the bishops constrained by the requirements of the Russian state law. This law was formulated in such a way as to enslave the hierarchy of the Catholic Church and lead to the extinction of the monastic life.

The Pauline monastery was threatened not only by the destructive actions of the Russian authorities but also by deepening internal crisis, which was used by the mentioned authorities. The Jasna Góra Monastery survived and was able to revive after the collapse of the tsarist rule in Częstochowa. Credit for this revival, in large part, goes to the rulers of the Diocese of Kujawy-Kalisz, who defended the monastery and at the same time tried to influence its spiritual rebirth.
\end{abstract}

